\title{
Instream Investigations in the Beaver Creek Watershed in West Tennessee, 1991-95
}

Compiled by TOM D. BYL and K.A. CARNEY

\section{U.S. GEOLOGICAL SURVEY}

Water-Resources Investigations Report 96-4186 


\section{U.S. DEPARTMENT OF THE INTERIOR BRUCE BABBITT, Secretary}

U.S. GEOLOGICAL SURVEY

Gordon P. Eaton, Director

The use of firm, trade, and brand names in this report is for identification purposes only and does not constitute endorsement by the U.S. Geological Survey.

For addtional information write to:

\section{District Chief}

U.S. Geological Survey

810 Broadway, Suite 500

Nashville, Tennessee 37203
Copies of this report can be purchased from:

U.S. Geological Survey Branch of Information Services Box 25286

Denver, CO 80225-0286 


\section{FOREWORD}

The U.S. Geological Survey (USGS), in cooperation with the Tennessee Department of Agriculture, began a long-term scientific investigation in 1989 to evaluate the effect of agricultural activities on water quality and the effectiveness of agricultural best management practices in the Beaver Creek watershed, West Tennessee. In 1993 as a part of this study, the USGS, in cooperation with the Natural Resources Conservation Service, Shelby County Soil and Water Conservation District, and the Tennessee Soybean Promotion Board, began an evaluation of the physical, chemical, biological, and hydrological factors that affect water quality in streams and wetlands, and instream resource-management systems to treat agricultural nonpoint-source runoff and improve water quality. The purpose of this report is to present the results of three studies of stream and wetland investigations and a study on the transport of aldicarb from an agricultural field in the Beaver Creek watershed.

A natural bottomland hardwood wetland and an artificially constructed wetland were evaluated as instream resource-management systems. These two studies showed that wetlands are an effective way to improve the quality of agricultural nonpoint-source runoff. The wetlands reduced concentrations and loads of suspended sediments, nutrients, and pesticides in the streams.

A third paper documents the influence of riparian vegetation on the biological structure and water quality of a small stream draining an agricultural field. A comparison of the upper reach lined with herbaceous plants and the lower reach with mature woody vegetation showed a more stable biological community structure and water-quality characteristics in the woody reach than in the herbaceous reach. The water-quality characteristics monitored were $\mathrm{pH}$, temperature, dissolved oxygen, and specific conductance. The herbaceous reach had a greater diversity and abundance of organisms during spring and early summer, but the abundance dropped by approximately 85 percent during late summer.

A fourth study describes the transport of aldicarb and its metabolites-aldicarb sulfoxide and aldicarb sulfone-in runoff at a small stream draining a cotton field. During 1991 to 1995, aldicarb and its metabolites were detected in runoff events. The highest concentrations occurred when aldicarb was applied to the field just hours before a rain storm. Aldicarb was not detectable in runoff a few weeks after application. The metabolites of aldicarb were detectable for 76 days after application.

These studies demonstrate that streambank vegetation and wetlands have a significant influence on stream water quality. The importance of weather conditions to herbicide application and runoff also is evident. This information can be used by resource managers to sustain and improve our Nation's streams for future generations.

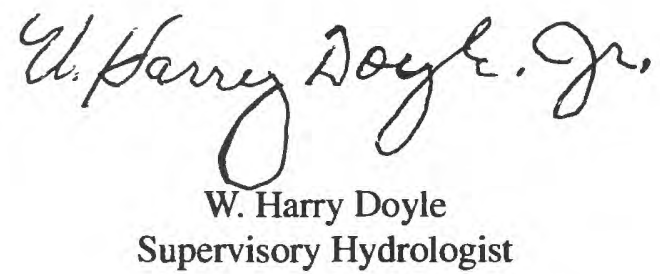





\section{CONTENTS}

Nutrient and sediment loads in a channelized stream and a nonchannelized wetland stream in the Beaver Creek watershed, West Tennessee

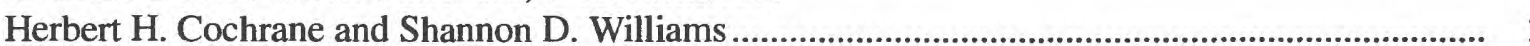

Evaluation of a constructed wetland to control agricultural row-crop nonpoint-source pollution

John A. Smink and Tom D. Byl

Influence of riparian vegetation on the biological structure and processing function of a channelized stream in West Tennessee

Tom D. Byl, Yun Jiao, Susan S. Hutson

Transport of aldicarb and aldicarb metabolites in runoff from agricultural fields in the Beaver Creek watershed, West Tennessee

Shannon D. Williams 


\section{CONVERSION FACTORS}

\begin{tabular}{rcl}
\hline Multiply & By & To obtain \\
\hline inch (in.) & 16.39 & centimeters \\
foot $(\mathrm{ft})$ & 0.3048 & meter \\
mile & 1.609 & kilometer \\
cubic foot $\left(\mathrm{ft}^{3}\right)$ & 0.02832 & cubic meter \\
cubic meter per second \\
acre & 0.02832 & hectare \\
acre-feet & 0.4047 & cubic meter \\
acre-feet & 1,233 & cubic hectometer \\
pound, avoirdupois & 0.001233 & kilogram \\
pounds per acre & 0.4536 & kilograms per hectare \\
ton, short & 1.1204 & megagram \\
\hline
\end{tabular}


Nutrient and Sediment Loads in a Channelized Stream and a Nonchannelized Wetland Stream in the Beaver Creek Watershed, West Tennessee

BY HERBERT H. COCHRANE and SHANNON D. WILLIAMS

U.S. GEOLOGICAL SURVEY

Prepared in cooperation with the Shelby County Soil and Water Conservation District and the U.S. Department of Agriculture, Natural Resources Conservation Service 



\section{Nutrient and Sediment Loads in a Channelized Stream and a Nonchannelized Wetland Stream in the Beaver Creek Watershed, West Tennessee}

\section{By Herbert H. Cochrane and Shannon D. Williams}

\section{Abstract}

In 1991, the U.S. Geological Survey began a research program to assess the effect of agriculture on water quality and the effectiveness of best management practices in the Beaver Creek watershed, West Tennessee. This report presents a comparison of nutrient and sediment concentrations and loads in a channelized stream and a nonchannelized stream that flows through a 600 -acre bottomland hardwood wetland. Both streams receive agricultural runoff from drainage basins of similar size (about 8,000 acres), land use, and topography.

Water samples were collected during three storm events in 1995; one prior to the planting of row crops and two during the growing season (April to September). Major differences in concentrations and loads of suspended sediment and nutrients were observed between the two streams. The channelized stream generally had higher concentrations and loads of suspended sediment and nutrients, even when it received less rainfall and had less storm runoff than the nonchannelized stream. Suspended-sediment loads ranged from 3.1 to 32 times greater at the channelized stream than at the nonchannelized/wetland stream during the three storms examined. Ammonia, nitrite and nitrate, and phosphorus loads ranged from 1.4 to 23 times greater at the channelized stream.

\section{INTRODUCTION}

Modifications of drainage networks by channelization are common in many agricultural watersheds (Hook, 1993; Reedy and Gale, 1994). Channelization has altered the hydrologic regime of many streams and wetland systems, potentially affecting the biological and nonbiological functions that are normally associated with these systems (Phillips, 1989; Gilliam, 1994; Lowrance and others, 1995). The nature and extent of the effects of channel modifications on streams in agricultural settings need to be understood to allow for the development and implementation of instream resource-management practices.

In 1991, the U.S. Geological Survey (USGS) began a research program to assess the effect of agriculture on water quality and the effectiveness of best management practices in the Beaver Creek watershed, West Tennessee. This report presents a comparison of nutrient and sediment concentrations and loads in a nonchannelized stream that flows through a 600 -acre bottomland hardwood wetland and a channelized stream. Both streams receive agricultural runoff from row crops. The study was conducted in cooperation with the Shelby County Soil and Water Conservation District and the U.S. Department of Agriculture, Natural Resources Conservation Service.

\section{STUDY AREA}

The drainage basins of the two streams compared in this study are contiguous basins of similar size, land use, and topography. The upper Middle Beaver Creek Canal basin (7,600 acres) represents a typical example of a channelized basin in the Beaver Creek watershed (fig. 1). The Baxter Bottom basin (8,000 acres) contains the only nonchannelized bottomland within the Beaver Creek watershed. A 600-acre hardwood wetland encompasses the main stem of this drainage network (fig.1). The forested wetland is believed to resemble prechannelized drainage conditions for bottomlands in the Beaver Creek watershed (Ashley, 1910). 


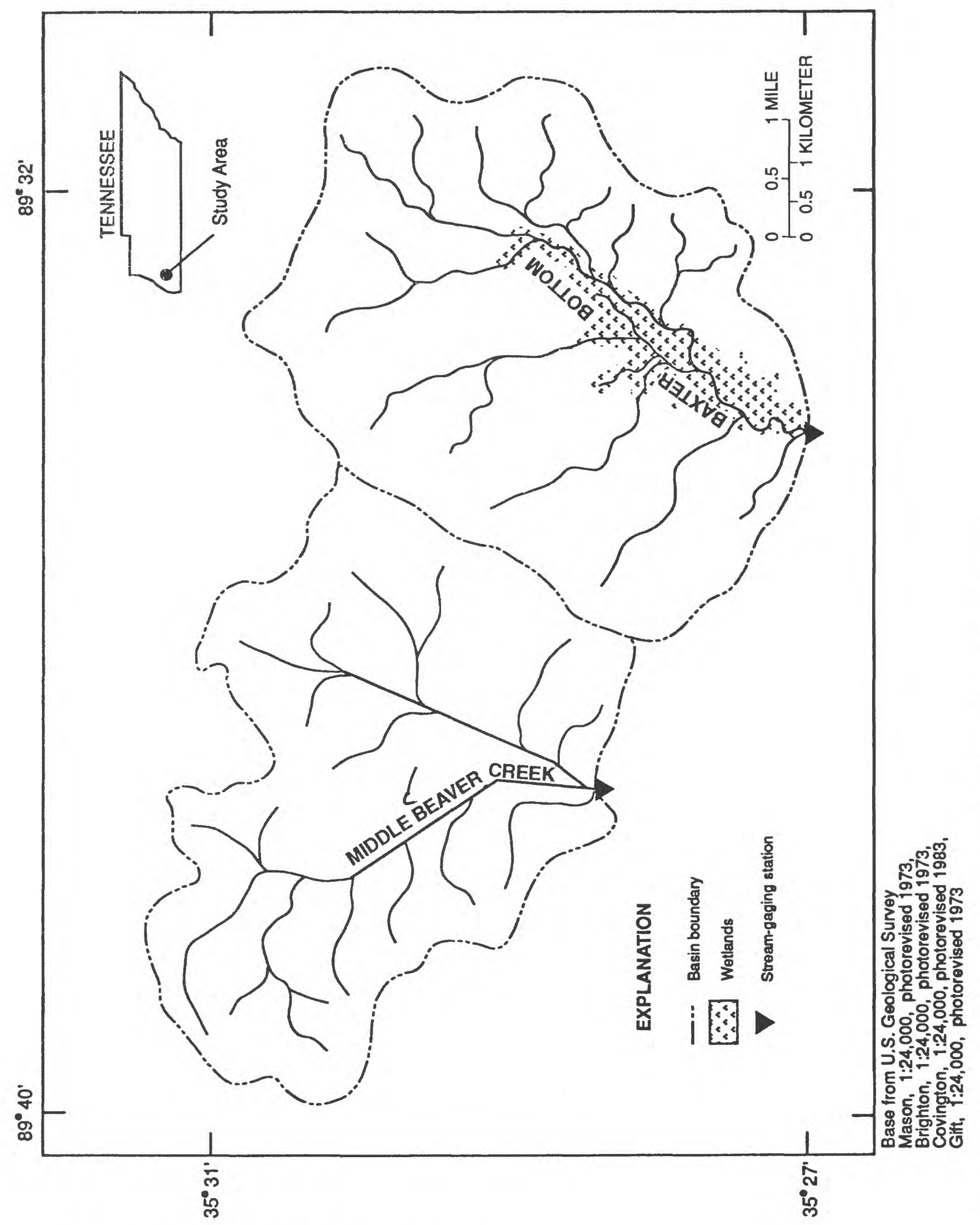

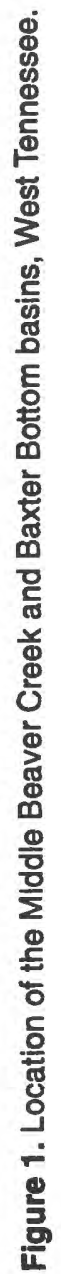


Land use in both basins is dominated by row crops; about 70 percent of the land is under cultivation. Crop distribution and fertilizer application rates are similar in the two basins; major crops grown are cotton, soybeans, corn, and winter wheat. Soils in the drainage basins consist of well to poorly drained silt loams, and slopes range from less than 1 percent in the bottomlands to 25 percent in the uplands (U.S. Department of Agriculture, Soil Conservation Service, 1993).

\section{DATA COLLECTION}

Discharge data were collected at USGS streamgaging stations located at the basin outlets. Rainfall data were collected at the Baxter Bottom gaging station; however, rainfall data for Middle Beaver Creek had to be estimated using data from surrounding sites because of a malfunctioning rain gage at this site.

Water samples were collected during three storm events; one prior to planting of row crops and two during the summer growing season. Samples were collected using two automatic samplers at each station-one for the collection of suspended-sediment samples and one for nutrient samples. Samplers were programmed to collect samples at 10-minute intervals at Middle Beaver Creek and at 30-minute intervals at Baxter Bottom during storm events. These intervals were selected after examining hydrographs for previous storm events at each site. Nutrient samples were analyzed at the UGSG Water-Quality Laboratory in Ocala, Fla., and sediment samples were analyzed at the USGS Sediment Laboratory in Tuscaloosa, Ala.

Discharge was calculated with stage-discharge rating curves developed by using methods described by Kennedy (1983). Event-mean concentrations for storms were calculated by dividing suspendedsediment and nutrient loads by storm-runoff volumes. Loads ( $L$ ) were calculated using the sum of individual interval loads:

$$
L=\sum_{i=1}^{n} c_{i} q_{i} t_{i} K,
$$

where

$c_{i}$ is the ith interval of sampled concentration,

$q_{i}$ is the instantaneous discharge at the time the sample was collected,

$t_{i}$ is the time interval associated with the sample,

$K$ is a unit conversion factor, and

$n$ is the number of samples.
This method assumes that the sampled concentration and the corresponding discharge value are representative of the time interval $t_{i}$, that is equal to half the time from the preceding sample to the current sample plus half the time from the current sample to the following sample.

\section{NUTRIENT AND SEDIMENT LOADS}

The hydrologic responses of Middle Beaver Creek and Baxter Bottom to storm events were different and can account for observed variances in nutrient and suspended-sediment concentrations and loads. Peak discharges at Middle Beaver Creek were higher and occurred sooner than at Baxter Bottom during similar rainfall events (fig. 2). The differences in the hydrologic responses can be attributed to differences in the physical features of the drainage basins. The Middle Beaver Creek basin has straighter channels because of channelization, and it also has a longer and narrower drainage area than the Baxter Bottom basin. Because of the faster response of the channelized stream, the storm-runoff duration was normally much shorter than for the nonchannelized stream.

The event-mean concentrations for suspended sediment and nutrients were generally greater at Middle Beaver Creek (table 1). The only exception was on March 26, 1995, when the mean organic nitrogen concentrations at the two streams were similar. During early spring, much of the organic nitrogen is from weathered plant material from the previous growing season, and little nitrification is taking place.

During the March 26, 1995 and May 18, 1995 events, greater storm-runoff volumes and greater sediment and nutrient loads occurred at Middle Beaver Creek (table 2). During the June 6, 1995 event, the storm-runoff volume at Baxter Bottom was 2.6 times greater than at Middle Beaver Creek. Despite the greater discharge on June 6 at Baxter Bottom, the total loads for various constituents at Middle Beaver Creek still ranged from 1.4 to 3.1 times greater than loads at Baxter Bottom.

Middle Beaver Creek usually had much higher loads of suspended sediment and nutrients than did Baxter Bottom (fig. 3). The exception was the organic nitrogen loads during the first storm (March 26, 1995). Suspended-sediment loads ranged from 3.1 to 32 times greater at Middle Beaver Creek than at Baxter Bottom. Although organic nitrogen loads for the two sites were similar during the March 26 event, they were 1.9 and 21 times greater at Middle Beaver Creek 

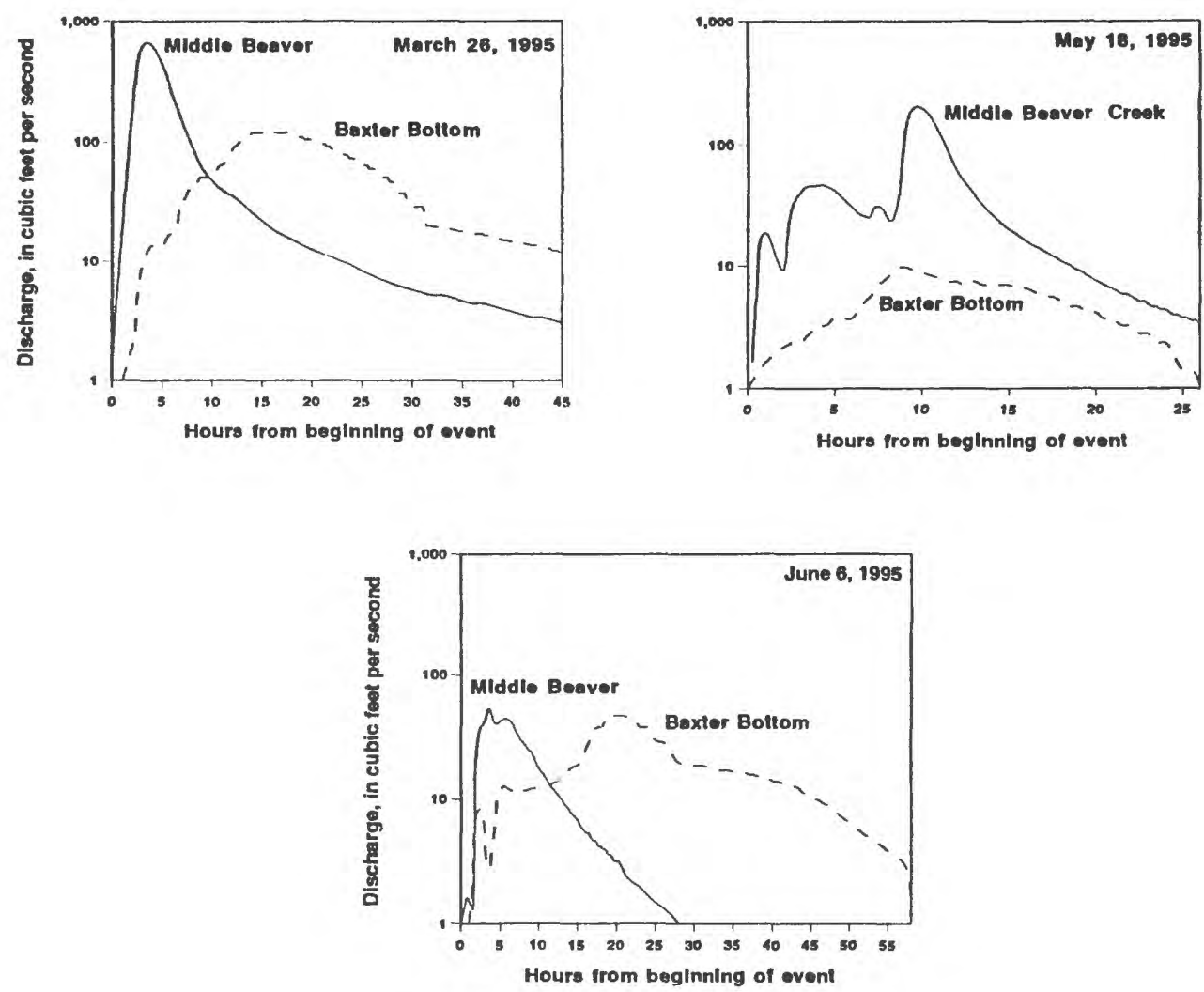

Figure 2. Hydrographs for selected storm-runoff events at Middle Beaver Creek and Baxter Bottom, West Tennessee.
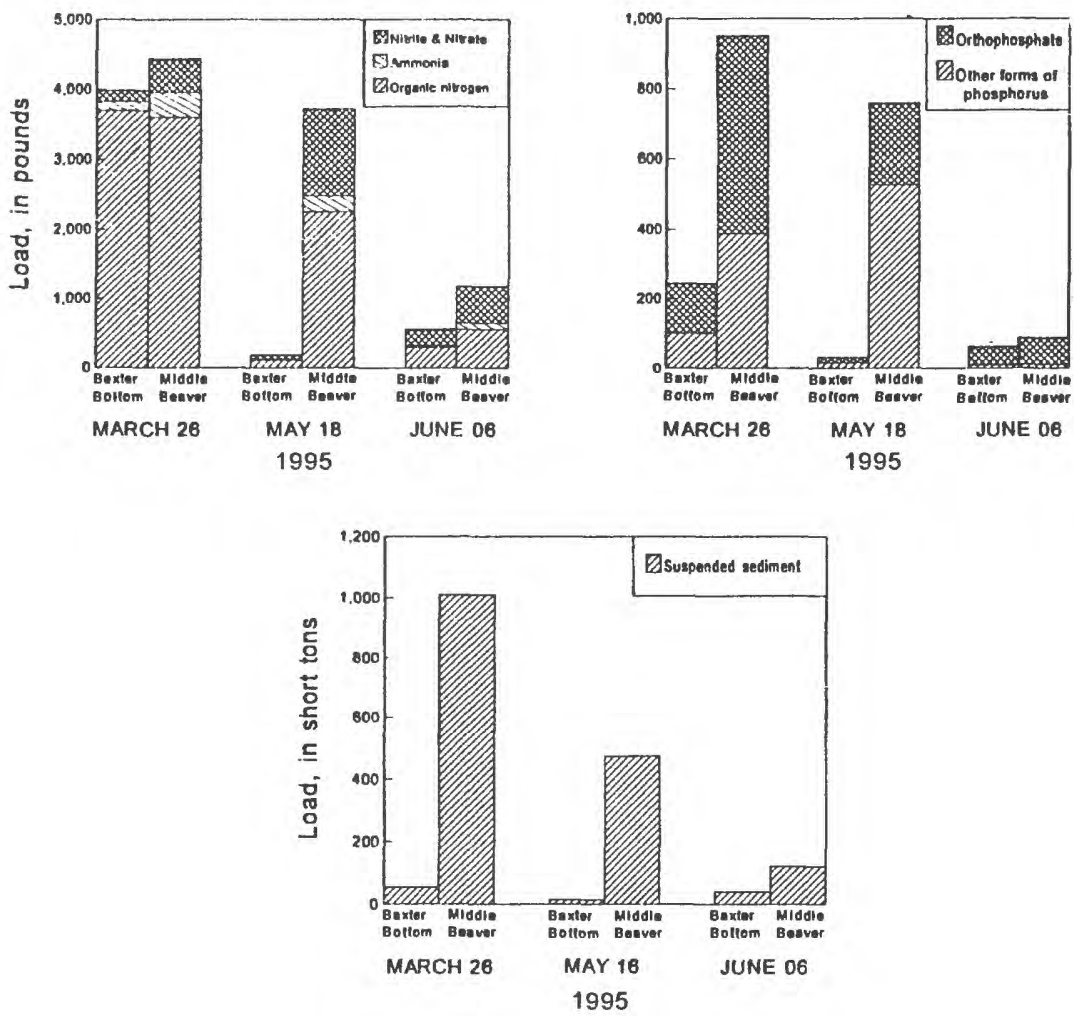

Figure 3. Nutrient and sediment loads during selected storm events at Middle Beaver Creek and Baxter Bottom, West Tennessee. 
Table 1. Event-mean concentrations and maximum concentrations of nutrients and suspended sediments for selected storms at Middle Beaver Creek and Baxter Bottom, West Tennessee, 1995

[Max., maximum; mg $/$, milligrams per liter]

\begin{tabular}{|c|c|c|c|c|c|c|c|c|c|c|c|c|c|}
\hline \multirow[b]{2}{*}{ Storm } & \multirow[b]{2}{*}{ Station } & \multicolumn{2}{|c|}{$\begin{array}{l}\text { Nitrogen, } \\
\text { organic }\end{array}$} & \multicolumn{2}{|c|}{$\begin{array}{l}\text { Nitrogen, } \\
\text { ammonia }\end{array}$} & \multicolumn{2}{|c|}{$\begin{array}{l}\text { Nitrogen, } \\
\text { nitrite and } \\
\text { nitrate }\end{array}$} & \multicolumn{2}{|c|}{$\begin{array}{c}\text { Phosphorus, } \\
\text { total }\end{array}$} & \multicolumn{2}{|c|}{$\begin{array}{c}\text { Phosphorus, } \\
\text { ortho- } \\
\text { phosphate }\end{array}$} & \multicolumn{2}{|c|}{$\begin{array}{l}\text { Suspended } \\
\text { Sediment }\end{array}$} \\
\hline & & $\begin{array}{l}\text { Mean } \\
(\mathrm{mg} / \mathrm{L})\end{array}$ & $\begin{array}{c}\text { Max. } \\
(\mathrm{mg} / \mathrm{L})\end{array}$ & $\begin{array}{c}\text { Mean } \\
(\mathrm{mg} / \mathrm{L})\end{array}$ & $\begin{array}{l}\text { Max. } \\
(\mathrm{mg} / \mathrm{L})\end{array}$ & $\begin{array}{c}\text { Mean } \\
(\mathrm{mg} / \mathrm{L})\end{array}$ & $\begin{array}{l}\text { Max. } \\
\text { (mg/L) }\end{array}$ & $\begin{array}{l}\text { Mean } \\
(\mathrm{mg} / \mathrm{L})\end{array}$ & $\begin{array}{c}\text { Max. } \\
(\mathrm{mg} / L)\end{array}$ & $\begin{array}{l}\text { Mean } \\
(m g / L)\end{array}$ & $\begin{array}{c}\text { Max. } \\
\text { (mg/L) }\end{array}$ & $\begin{array}{l}\text { Mean } \\
(\mathrm{mg} /)\end{array}$ & $\begin{array}{l}\text { Max. } \\
(\mathrm{mg} / \mathrm{L})\end{array}$ \\
\hline \multirow[t]{2}{*}{$03 / 26 / 95$} & Middle Beaver & 5.7 & 6.9 & 0.5 & 0.8 & 0.8 & 1.1 & 1.5 & 3.1 & 0.9 & 1.1 & 3,233 & 7,193 \\
\hline & Baxter Bottom & 7.5 & 13.0 & 0.3 & 1.0 & 0.3 & 1.5 & 0.5 & 1.2 & 0.3 & 0.8 & 213 & 2,767 \\
\hline \multirow[t]{2}{*}{$05 / 18 / 95$} & Middle Beaver & 10.9 & 19.0 & 1.1 & 2.2 & 6.0 & 17.0 & 3.5 & 7.4 & 1.1 & 2.0 & 4,621 & 14,755 \\
\hline & Baxter Bottom & 3.9 & 6.9 & 0.7 & 1.2 & 2.1 & 2.9 & 1.1 & 1.4 & 0.5 & 0.8 & 1,087 & 1,365 \\
\hline \multirow[t]{2}{*}{$06 / 06 / 95$} & Middle Beaver & 6.6 & 21.0 & 1.0 & 2.1 & 6.2 & 9.3 & 1.0 & 1.5 & 0.9 & 1.4 & 2,890 & 9,877 \\
\hline & Baxter Bottom & 1.4 & 8.5 & 0.1 & 1.5 & 1.1 & 9.3 & 0.3 & 1.3 & 0.2 & 1.3 & 360 & 6,676 \\
\hline
\end{tabular}

Table 2. Rainfall and discharge, and sediment and nutrient loads for selected storms at Middle Beaver Creek and Baxter Bottom, West Tennessee, 1995

$\left[\mathrm{ft}^{3} / \mathrm{s}\right.$, cubic feet per second; $\mathrm{ft}^{3}$, cubic feet; lbs, pounds; *, estimated values]

\begin{tabular}{|c|c|c|c|c|c|c|c|c|c|c|}
\hline \multirow[b]{2}{*}{ Storm } & \multirow[b]{2}{*}{ Station } & \multirow[b]{2}{*}{$\begin{array}{l}\text { Rainfall } \\
\text { (inches) }\end{array}$} & \multirow[b]{2}{*}{$\begin{array}{c}\text { Peak } \\
\text { discharge } \\
\left(\mathrm{ft}^{3} / \mathrm{s}\right)\end{array}$} & \multirow[b]{2}{*}{$\begin{array}{c}\text { Storm } \\
\text { runoff } \\
\text { volume } \\
\left(\mathrm{ft}^{3}\right)\end{array}$} & \multicolumn{6}{|c|}{ Storm Loads } \\
\hline & & & & & $\begin{array}{c}\text { Nitrogen, } \\
\text { Organic } \\
\text { (lbs) }\end{array}$ & $\begin{array}{l}\text { Nitrogen, } \\
\text { ammonia } \\
\text { (Ibs) }\end{array}$ & $\begin{array}{l}\text { Nitrogen, } \\
\text { nitrite } \\
\text { and } \\
\text { nitrate } \\
\text { (lbs) }\end{array}$ & $\begin{array}{c}\text { Phos- } \\
\text { phorus, } \\
\text { total } \\
\text { (Ibs) }\end{array}$ & $\begin{array}{c}\text { Phos- } \\
\text { phorus, } \\
\text { ortho- } \\
\text { phosphele } \\
\text { (lbs) }\end{array}$ & $\begin{array}{l}\text { Suspended } \\
\text { sediment } \\
\text { (short tons) }\end{array}$ \\
\hline \multirow[t]{2}{*}{$03 / 26 / 95$} & Middle Beaver & $* 1.0$ & 659 & $10,000,000$ & 3,590 & 362 & 478 & 950 & 562 & 1,010 \\
\hline & Baxter Bottom & 0.7 & 122 & $8,210,000$ & 3,690 & 132 & 159 & 243 & 141 & 55 \\
\hline \multirow[t]{2}{*}{$05 / 18 / 95$} & Middle Beaver & $* 0.8$ & 200 & $3,290,000$ & 2,260 & 220 & 1,240 & 728 & 231 & 475 \\
\hline & Baxter Bottom & 0.8 & 10 & 445,000 & 108 & 20 & 57 & 31 & 15 & 15 \\
\hline \multirow[t]{2}{*}{$06 / 06 / 95$} & Middle Beaver & $* 0.7$ & 53 & $1,350,000$ & 562 & 88 & 527 & 88 & 77 & 122 \\
\hline & Baxter Bottom & 1.0 & 47 & $3,560,000$ & 302 & 29 & 236 & 62 & 53 & 40 \\
\hline
\end{tabular}


during the other two events (May 18, 1995 and June 6, 1995). Ammonia, nitrite and nitrate, and phosphorus loads ranged from 1.4 to 23 times greater at Middle Beaver Creek during the three events examined.

The quick hydrologic response and fast runoff at the Middle Beaver Creek may reduce the ability of this system to assimilate nutrients. The fast flowing water may allow for little settling of sediments and may enhance stream bed and bank erosion, contributing to additional sediment load. The longer retention time of water in the nonchannelized/wetland stream as compared to the channelized stream and the biogeochemical processes associated with wetlands in the nonchannelized stream may allow this system to function as a sink for nutrients and suspended sediments.

These findings further document the ability of natural streams and wetland areas to reduce waterquality degradation. These findings indicate that preserving the biological and hydrological functions of natural wetlands in agricultural areas may be an integral part of instream and watershed management practices used to reduce nonpoint-source pollution.

\section{SUMMARY}

Modifications of drainage networks by channelization has altered the hydrologic regime of many streams and wetland systems, potentially affecting the biological and nonbiological functions that are normally associated with these systems. In 1995, the U.S. Geological Survey completed a study comparing the drainage basins of two streams that are similar in size, land use, and topography. The primary difference between the two basins is the drainage networks; the upper Middle Beaver Creek Canal basin (7,600 acres) has been channelized, but the Baxter Bottom basin $(8,000$ acres) contains the only nonchannelized bottomland within the Beaver Creek watershed and flows through a 600-acre bottomland hardwood wetland. About 70 percent of the land in both basins is under cultivation.

Water samples were collected at 10- and 30minute intervals during three storm events: one prior to the planting of row crops and two during the summer growing season (April to September). Peak discharges at Middle Beaver Creek were higher and occurred sooner than at Baxter Bottom during similar rainfall events. The data from the storms of March 26, May 18, and June 6,1995, indicate that significant differences in concentrations and loads of nutrients and sediment are evident in the two streams. Because of the faster response of Middle Beaver Creek, the stormrunoff duration was normally much shorter than for Baxter Bottom. Middle Beaver Creek generally had higher concentrations and loads of suspended sediment and nutrients, even when it received less rainfall and had less storm runoff than Baxter Bottom.

During the June 6, 1995 storm event, the stormrunoff volume at Baxter Bottom was 2.6 times greater than at Middle Beaver Creek. Despite the greater discharge on June 6 at Baxter Bottom, the total loads for various constituents at Middle Beaver Creek still ranged from 1.4 to 3.1 times greater than loads at Baxter Bottom. Suspended-sediment loads ranged from 3.1 to 32 times greater at the channelized stream (Middle Beaver Creek) than at the nonchannelized/wetland stream (Baxter Bottom). Ammonia, nitrite and nitrate, and phosphorus loads ranged from 1.4 to 32 times greater at the channelized stream than the nonchannelized stream.

The results indicate that natural streams and wetland areas may lessen water-quality degradation. Results also indicate that preserving wetlands in agricultural areas may be an integral part of instream resource-management practices available for use in reducing nonpoint-source pollution.

\section{SELECTED REFERENCES}

Ashley, G.H., 1910, Drainage problems in Tennessee: Tennessee State Geological Survey Bulletin, 3-A, p. 1-15.

Gilliam, J.W., 1994, Riparian wetlands and water quality: Journal of Environmental Quality, v. 23, p. 896-900.

Hook, D.D., 1993, Wetlands: History, current status, and future: Environmental Toxicology and Chemistry, v. 12, p. $2157-2166$.

Kennedy, E.G., 1983, Computation of continuous records of streamflow: U.S. Geological Survey Techniques of Water Resources Investigations, Book 3, chapter A13, $53 \mathrm{p}$.

Lowrance, R., Vellidis, G., and Hubbard, R.K., 1995, Wetland and aquatic processes: Denitrification in a restored riparian forest wetland: Journal of Environmental Quality, v. 24, p. 808-815.

Petersen, L.B.M., and Petersen, R.C., 1991, Short term retention properties of channelized and natural streams: Internationale Vereinigugn fuer Theoretische und Angewandte Limnologie, v. 24, no. 3, p. 1756-1759.

Phillips, J.D., 1989, Fluvial sediment storage in wetlands: Water Resources Bulletin, v. 25, n. 4, p. 867-873.

Reddy, K.R., and Gale, P.M., 1994, Wetland processes and water quality: A symposium overview: Journal of Environmental Quality, v. 23, p. 875-877.

U.S. Department of Agriculture, Soil Conservation Service, 1993, Soil survey of Tipton County, Tennessee: Washington, D.C., U.S. Government Printing Office, 102 p. 


\section{Evaluation of a Constructed Wetland to Control}

Agricultural Row-Crop Nonpoint-Source Pollution

By JOHN A. SMINK and TOM D. BYL

U.S. GEOLOGICAL SURVEY

Prepared in cooperation with the Shelby County Soil and Water Conservation District, Tennessee Soybean Promotion Board, and the U.S. Department of Agriculture, Natural Resources Conservation Service 


\title{
Evaluation of a Constructed Wetland to Control Agricultural Row-Crop Nonpoint-Source Pollution
}

\author{
By John A. Smink and Tom D. Byl
}

\section{Abstract}

As water flows through wetlands, water quality is modified because of physical, chemical, and biological processes. Humans have taken advantage of this attribute to treat wastewater, acid mine drainage, and industrial point-source discharge. Recently, constructed wetlands have been used to treat agricultural runoff from feedlots and animal facilities. A constructed wetland was evaluated to determine the feasibility of using wetlands to improve the quality of storm-water runoff from soybean fields in West Tennessee. The 1.5-year-old constructed wetland discussed in this study was effective in reducing nitrogen loads by 46 percent, phosphorous loads by 41 percent, suspended-sediment loads by 67 percent, metolachlor loads by 51 percent, and acifluorfen loads by 90 percent during the five storms sampled. These results demonstrate that constructed wetlands are capable of reducing row-crop runoff and improving water quality.

\section{INTRODUCTION}

Nonpoint-source (NPS) pollution has been identified as a major cause of surface-water impairment in the United States (U.S. Environmental Protection Agency, 1989). Created, restored, and natural wetlands can contribute significantly to improving water quality (Olson, 1993). Extensive research has been conducted using wetlands to treat wastewater from industrial, agricultural, and municipal sources (Kadlec and Kadlec, 1979). The results indicate wetlands can effectively remove heavy metals, nutrients, and total suspended solids from point sources (Suurballe, 1991). Because wetlands have an intrinsic ability to reduce pollution from point sources, they show great potential as a method for reducing nonpoint-source pollution. The Des Plaines River Wetlands Demonstration Project effectively reduced sediment, phosphorus, and atrazine loads from pumped river water in an agricultural and urban watershed (Kadlec and Bastiens, 1992). Wetlands also have been effective in reducing chemical oxygen demand and buffering acids from acid mine drainage, as well as in sequestering metals from metal mine drainage (Eger, 1994). Because of these successes, the use of constructed wetlands has gained popularity for controlling nonpoint-source pollution from urban areas, silviculture activities, construction, and mining activities.

Recently, wetlands have been constructed to improve the quality of water in agricultural runoff from feedlots and animal-production facilities (MacDonald, 1994). These constructed wetlands are low maintenance processors which reduce animal-waste pollution by chemical, physical, and biological reactions. In spite of the successful use of constructed wetlands for these purposes, little research has been directed toward using constructed wetlands to control agricultural NPS pollution from row crops. Wetlands have the potential to improve water quality by assimilating nutrients and pesticides, thereby reducing the load carried into the streams by storm runoff. Wetlands act as sediment traps and reduce sediment transport into larger bodies of water. Wetlands have been shown to reduce the erosive powers of floods by moderating peak discharges and releasing storm water slowly (Novitzki, 1979). Wetlands provide these benefits at low cost.

Efforts have been made by the agricultural community to reduce agricultural NPS pollution by implementing best management practices (BMP's). However, these efforts have not always had the desired effect. This lack of success may be due to 
overwhelming weather conditions or the selection of an inappropriate BMP for the Beaver Creek region. Therefore, modified and new BMP's have been encouraged and evaluated in the Beaver Creek Hydrologic Unit Area to optimize their effectiveness. Constructed wetlands are one type of BMP that has potential to control or reduce NPS pollution in the agricultural rich Mississippi embayment.

This report discusses the results of a project that evaluated the effectiveness of a constructed wetland to improve water quality from agricultural row-crop runoff. The experimental design was an upstreamdownstream approach. Runoff was sampled as the water entered and exited the wetland. An intensive sampling program was designed to collect water samples through the entire runoff period of individual storms. The samples were analyzed for suspended sediment and selected pesticides and nutrients. The results of these activities were used to evaluate the ability of a constructed wetland to reduce NPS pollution from storm runoff. This project was conducted from March to August 1995 by the U.S. Geological Survey, in cooperation with Shelby County Soil and Water Conservation District, Tennessee Soybean Promotion Board, and the U.S. Department of Agriculture, Natural Resources Conservation Service.

\section{ACKNOWLEGDMENTS}

Thanks to John Charles Wilson for allowing the authors to conduct these studies on his property.

\section{DATA COLLECTION}

In fall 1993, a constructed wetland cell, planted with cattails and bulrushes, was built in the Beaver Creek watershed in West Tennessee (fig. 1), which is in the Mississippi embayment. The constructed wetland cell is rectangular in shape and is approximately 0.88 acre. Maximum storage capacity of the cell is about 76,700 cubic feet, and it can hold as much as 2 feet of water before outflow begins to discharge through an outlet flume. The wetland receives runoff from two row-crop fields. These fields are relatively flat, and the elevated rows have been oriented to move stormwater into a drainage ditch and subsequently into the wetland cell. The drainage ditch enters the constructed wetland at the north end; water spreads out and flows the length of the wetland cell and exits the south end into a larger ditch.
Both fields that drain into the constructed wetland were planted exclusively in soybeans in 1995 using conventional planting methods. The size of the field farthest from the constructed wetland is 20 acres and that of the closer field is 27 acres. The soil in the smaller field is a combination of Waverly and Falaya loess silty loam, and the larger field is predominately Waverly loess silty loam. Both fields have less than a 5 -percent grade. The fields are classified as "bottom land" by the Shelby County Soil and Water Conservation District and are part of the West Beaver Creek flood plain.

U.S. Geological Survey (USGS) gaging stations were constructed at the inlet and the outlet of the wetland cell. Each station was equipped with stage recording instruments and two automatic samplers.

One automatic sampler at each station collected water samples for nutrient and pesticide analyses, and the second sampler collected samples for suspendedsediment analyses. A tipping-bucket rain gage recorded rainfall at the wetland cell. Liquid-level actuators were used to automatically initiate the sampling program at the beginning of a runoff event. Samples used for nutrient and herbicide (metolachlor and acifluorfen) analyses were immediately placed on ice and shipped to contract analytical laboratories. Total suspended-sediment samples were labeled and analyzed within a few weeks after collection.

The samples used for nutrient and herbicide analyses were kept on ice, labeled, and shipped for rapid delivery to the analytical laboratories. Samples for suspended-sediment analyses were analyzed by the USGS Sediment Laboratory in Tuscaloosa, Alabama. Samples for nutrient and metolachlor analyses were analyzed by the USGS Laboratory in Ocala, Florida. Acifluorfen analyses were performed by a contract laboratory (Quanterra) in Arvada, Colorado.

Metolachlor and acifluorfen were the two herbicides selected for analyses because they were applied to both fields. Metolachlor is a pre-emergent herbicide, which is applied just prior to planting or in conjunction with planting. Acifluorfen is a postemergent herbicide, which is applied several weeks after plant germination. Metolachlor was applied to the smaller field on June 17, 1995. Acifluorfen was applied to the larger field on June 17, 1995. Stormrunoff samples were collected on March 27 prior to planting or herbicide application to establish preplanting concentrations of nutrients, suspended sediments, and herbicides. Intensive storm runoff 


\section{TENNESSEE}

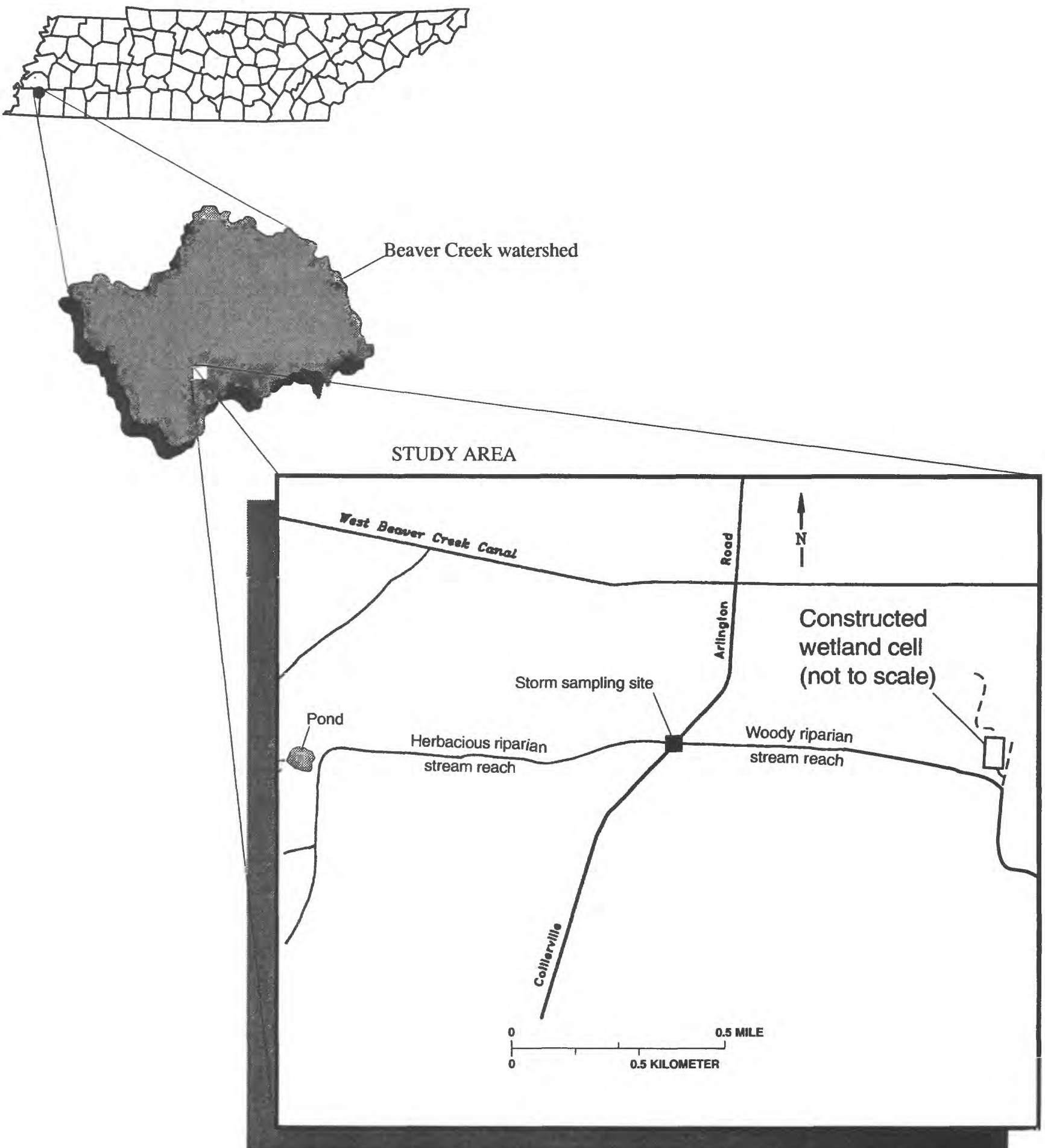

Figure 1. Location of the constructed wetland in the Beaver Creek watershed, West Tennessee. 
sampling was re-initiated after the fields were simultaneously tilled, planted, and sprayed in early June. The storm sampling continued through August. Four storm runoff events occurred from June to midAugust 1995. Water samples for nutrient, suspended sediment, and metolachlor analyses were collected during each of the four runoff events. The only water samples for acifluorfen analyses were collected during the initial screening and the fourth storm because this herbicide was not applied until after the third storm.

The number of samples per storm was dictated by the length of the storm and runoff hydrograph. Not having advance knowledge of intensity, size, or length of any storm, runoff samples were collected at 10- to 15-minute intervals for the duration of each storm event. After all samples were collected and returned to the processing lab, a subset of samples was selected to represent the storm-runoff event. More samples were analyzed corresponding to the beginning of storm events because the stage rose fairly quickly compared to the relatively slow descent at the end of the storm. This sampling strategy was designed to provide greater sensitivity during the first flush of the event.

Discharge was calculated with stage-discharge rating curves developed by using methods described by Kennedy (1983). Loads $(L)$ were calculated by using the sum of individual interval loads:

$$
L=\sum_{i=1}^{n} c_{i} q_{i} t_{i} K,
$$

where

$c_{i}$ is the ith interval of sampled concentration,

$q_{i}$ is the instantaneous discharge at the time the sample was collected,

$t_{i}$ is the time interval associated with the sample,

$K$ is a unit conversion factor, and

$n$ is the number of samples.

This method assumes that the sampled concentration and the corresponding discharge value are representative of the time interval $t_{i}$, that is equal to half the time from the preceding sample to the current sample plus half the time from the current sample to the following sample.

\section{EVALUATION OF CONSTRUCTED WETLAND}

A range of storm intensities and runoff conditions occurred during the test period (table 1). Obser- vations were made that runoff in the inflow ditch was of short duration, stopping soon after the rain ceased. The wetland had no outflow during the July 20 storm because the water surface in it did not rise to the level of the discharge flume. The first and last storms had relatively equal volumes of water flowing in and out. The storm of March 27, 1995, had a total inflow volume of 38,600 cubic feet $\left(\mathrm{ft}^{3}\right)$ and a total outflow volume of $38,500 \mathrm{ft}^{3}$. The storm of August 4, 1995, had inflow of $313,000 \mathrm{ft}^{3}$ and outflow of $313,000 \mathrm{ft}^{3}$.

The effectiveness of the constructed wetland was measured by its ability to reduce total loads and peak concentrations (data not shown) of nutrients, suspended sediment, and herbicides. The analysis was made by comparing water quality at the inlet and outlet of the constructed wetland. Average concentrations for nutrients ranged from 0.3 to 6.6 milligrams per liter $(\mathrm{mg} / \mathrm{L})$ for inflow, and from 0.2 to $5.7 \mathrm{mg} / \mathrm{L}$ for outflow; suspended sediment ranged from 97 to $456 \mathrm{mg} / \mathrm{L}$ for inflow and from 22 to $79 \mathrm{mg} / \mathrm{L}$ for outflow; herbicides ranged from 0.25 to 16.0 micrograms per liter $(\mu \mathrm{g} / \mathrm{L})$ for inflow and from 0.11 to $1.67 \mu \mathrm{g} / \mathrm{L}$ for outflow. In general, average concentrations of nutrients, suspended sediment, and herbicides were higher at the inlet station than at the outlet station (table 2).

Total loads for nutrients, suspended sediment, and herbicides generally were higher at the inlet sample station compared to the downstream outlet sample station (table 3 ). Average loads for nutrients ranged from 0.4 to 102.3 pounds for inflow and from 0.4 to 43.2 pounds for outflow; suspended-sediment loads ranged from 765 to 1,877 pounds for inflow and from 115 to 1,012 pounds for outflow; herbicide loads ranged from 0.01 to 5.0 ounces for inflow and from less than 0.01 to 0.52 ounces for outflow. For the July 22 storm, however, nitrogen load was slightly higher for outflow (13.2 pounds) than for inflow (13.0 pounds). This result was probably because the storm event 2 days earlier brought in nutrients and sediment, but the wetland did not discharge any water on that date. Inflow from the storm on July 22 was sufficient to raise the water level and push some of the enriched water out by displacement.

The five-storm load for total nitrogen was 140 pounds at the inlet and 76 pounds at the outlet (table 3 ). These total loads were used to calculate the reduction in NPS contaminants as percentages (table 4). The wetland cell reduced the total-nitrogen export by approximately 
46 percent during the study period. The fivestorm load for total phosphorous was 16.7 pounds at the inlet and 9.8 pounds at the outlet; a reduction of 41 percent. The five-storm suspendedsediment load was reduced from 5,812 pounds at the inlet to 1,942 pounds at the outlet, a reduction of 67 percent. Metolachlor loads were reduced from 0.41 ounces at the inlet to 0.20 ounces at the outlet. Thus, the wetland cell reduced 51 percent of the metolachlor load during the study period. The final storm was the only one with measurable concentrations of acifluorfen in runoff. This herbicide was reduced by 90 percent at the outflow.

\section{SUMMARY AND DISCUSSION}

Nonpoint-source pollution has been identified as a major source of surface-water impairment in the United States. The purpose of this study was to evaluate the effectiveness of a wetland constructed in fall 1993 in improving water quality. Two bottom land fields ( 20 and 27 acres) that drain into the constructed wetland were planted exclusively in soybean using conventional planting methods. The constructed wet- land intercepts runoff water from these fields before the water enters the Beaver Creek drainage network.

Gaging stations were constructed at the inlet and the outlet of the wetland cell. Each station was equipped with a stage recording instrument and two automatic samplers. Storm runoff was sampled as it entered and exited the wetland to determine the effect of the wetland on reducing row-crop runoff and on improving the quality of water from runoff.

Storm-runoff samples were collected on March 27, 1995, prior to planting or herbicide application to establish pre-planting concentrations of nitrogen, phosphorus, suspended sediment, metolachlor, and acifluorfen. Metolachlor, a pre-emergent herbicide, was applied to the 20-acre field on June 17, 1995; and acifluorfen, a post-emergent herbicide, was applied to the 27-acre field also on June 17. Storm runoff from four storms was sampled from mid-June through August.

The wetland had no outflow during the July 20 storm, but the first and last storms each had about the same amount of inflow $(38,600$ and $\left.313,000 \mathrm{ft}^{3}\right)$ as they did outflow $(38,500$ and $313,000 \mathrm{ft}^{3}$ ). In general, average concentrations of nutrients, suspended sediment, and herbicides were higher at the inlet station than at the outlet

Table 1. Storm duration, rainfall, runoff depth, total volume of runoff into and out of the wetland cell $\left[--=\right.$ no data; in. = inches; $\mathrm{ft}^{3}=$ cubic feet $]$

\begin{tabular}{|c|c|c|c|c|c|}
\hline \multirow{2}{*}{$\begin{array}{c}\text { Storm } \\
\text { date }\end{array}$} & \multirow{2}{*}{$\begin{array}{l}\text { Duration of } \\
\text { stormflow }\end{array}$} & \multirow{2}{*}{$\begin{array}{c}\text { Rainfall } \\
\text { (in.) }\end{array}$} & \multirow{2}{*}{$\begin{array}{c}\text { Runoff } \\
\text { depth (in.) }\end{array}$} & \multicolumn{2}{|c|}{ Total volume } \\
\hline & & & & Inflow $\left(\mathrm{ft}^{3}\right)$ & Outflow $\left(\mathrm{ft}^{3}\right)$ \\
\hline $03 / 27 / 95$ & - & 0.5 & 0.22 & 38,600 & 38,500 \\
\hline 07/05/95 & 42 hours & 2.0 & 0.51 & 87,500 & 76,100 \\
\hline $07 / 20 / 95$ & 22 hours & 1.1 & 0.02 & 2,700 & 0 \\
\hline $07 / 22 / 95$ & 66 hours & 3.2 & 1.29 & 220,200 & 208,400 \\
\hline 08/04/95 & 71 hours & 4.1 & 1.83 & 313,000 & 313,000 \\
\hline
\end{tabular}

Table 2. Average concentration of total nitrogen, phosphorous, suspended sediment, metolachlor, and acifluorfen for five storm events at the wetland cell

[ $\mathrm{mg} / \mathrm{L}=$ milligrams per liter; $\mu \mathrm{g} / \mathrm{L}=$ micrograms per liter; $-=$ no data, prior to application; \# = no discharge]

\begin{tabular}{|c|c|c|c|c|c|c|c|c|c|c|}
\hline \multirow[t]{2}{*}{$\begin{array}{l}\text { Storm } \\
\text { date }\end{array}$} & \multicolumn{2}{|c|}{$\begin{array}{l}\text { Nitrogen, } \\
\text { total } \\
(\mathrm{mg} / \mathrm{L})\end{array}$} & \multicolumn{2}{|c|}{$\begin{array}{c}\text { Phosphorous, } \\
\text { total } \\
\text { (mg/L) }\end{array}$} & \multicolumn{2}{|c|}{$\begin{array}{l}\text { Suspended } \\
\text { sediment } \\
\text { (mg/L) }\end{array}$} & \multicolumn{2}{|c|}{$\begin{array}{l}\text { Metolachlor } \\
(\mu \mathrm{g} / \mathrm{L})\end{array}$} & \multicolumn{2}{|c|}{$\begin{array}{c}\text { Acifluorien } \\
(\mu g / L)\end{array}$} \\
\hline & Tnflow & Outflow & Inflow & Outtlow & Inflow & Outflow & Intlow & Outtlow & Tntiow & Outiow \\
\hline $03 / 27 / 95$ & 6.6 & 5.7 & 0.6 & 0.2 & 329 & 47 & 0.25 & 0.11 & -- & -- \\
\hline $07 / 05 / 95$ & 1.6 & 1.3 & 0.7 & 0.4 & 171 & 79 & 1.83 & 1.31 & - & - \\
\hline $07 / 20 / 95$ & 2.5 & \# & 1.4 & $\#$ & 456 & \# & 0.50 & \# & -- & -- \\
\hline $07 / 22 / 95$ & 1.0 & 1.0 & 0.3 & 0.3 & 104 & 78 & 0.46 & 0.44 & - & - \\
\hline 08/04/95 & 5.2 & 2.2 & 0.3 & 0.2 & 97 & 22 & -- & - & 16.0 & 1.67 \\
\hline
\end{tabular}


Table 3. Total storm loads of nitrogen, phosphorous, suspended sediment, metolachlor, and acifluorfen in the wetland inflow and outflow

[\# = no discharge; -- = no data; $<=$ less than]

\begin{tabular}{|c|c|c|c|c|c|c|c|c|c|c|}
\hline \multirow[t]{2}{*}{$\begin{array}{c}\text { Storm } \\
\text { date }\end{array}$} & \multicolumn{2}{|c|}{$\begin{array}{c}\text { Nitrogen, } \\
\text { total } \\
\text { (pounds) }\end{array}$} & \multicolumn{2}{|c|}{$\begin{array}{c}\text { Phosphorous, } \\
\text { total } \\
\text { (pounds) }\end{array}$} & \multicolumn{2}{|c|}{$\begin{array}{l}\text { Suspended } \\
\text { sediment } \\
\text { (pounds) }\end{array}$} & \multicolumn{2}{|c|}{$\begin{array}{l}\text { Metolachlor } \\
\text { (ounces) }\end{array}$} & \multicolumn{2}{|c|}{$\begin{array}{l}\text { Acifluorfen } \\
\text { (ounces) }\end{array}$} \\
\hline & Inflow & Outflow & Inflow & Outflow & Inflow & Outflow & Inflow & Outflow & Inflow & Outflow \\
\hline $03 / 27 / 95$ & 15.9 & 13.9 & 1.5 & 0.4 & 796 & 115 & 0.01 & $<0.01$ & -- & - \\
\hline $07 / 05 / 95$ & 8.6 & 5.9 & 3.5 & 2.2 & 942 & 384 & 0.16 & 0.10 & -- & - \\
\hline $07 / 20 / 95$ & 0.4 & $\#$ & 2.4 & $\#$ & 765 & $\#$ & 0.14 & $\#$ & - & -. \\
\hline $07 / 22 / 95$ & 13.0 & 13.2 & 4.2 & 3.7 & 1,422 & 1,012 & 0.10 & 0.09 & -. & - \\
\hline 08/04/95 & 102.3 & 43.2 & 5.1 & 3.5 & 1,887 & 432 & -- & -- & 5.0 & 0.52 \\
\hline Total & 140.2 & 76.2 & 16.7 & 9.8 & 5,812 & 1,942 & 0.41 & 0.20 & 5.0 & 0.52 \\
\hline
\end{tabular}

Table 4. Percentage reduction in storm loads of nitrogen, phosphorous, metolachlor, and acifluorfen at wetland outflow for five storm events

[Storm 7/20/95 was combined with 7/22/95 to calculate the percentage of reduction because there was no discharge during 7/20/95; $\mathrm{e}=$ estimated; $--=$ no data]

\begin{tabular}{cccccc}
\hline $\begin{array}{c}\text { Storm } \\
\text { date }\end{array}$ & $\begin{array}{c}\text { Nitrogen } \\
\text { total } \\
\text { (percent) }\end{array}$ & $\begin{array}{c}\text { Phosphorous } \\
\text { total } \\
\text { (percent) }\end{array}$ & $\begin{array}{c}\text { Suspended } \\
\text { sediment } \\
\text { (percent) }\end{array}$ & $\begin{array}{c}\text { Metolachlor } \\
\text { (percent) }\end{array}$ & $\begin{array}{c}\text { Acifluorfen } \\
\text { (percent) }\end{array}$ \\
\hline $03 / 27 / 95$ & 13 & 73 & 86 & $60 \mathrm{e}$ & -- \\
$07 / 05 / 95$ & 31 & 37 & 59 & $36 \mathrm{e}$ & -- \\
$07 / 20+22 / 95$ & 2 & 44 & 54 & 62 & -- \\
$08 / 04 / 95$ & 58 & 31 & 77 & 51 & 90 \\
Total & 46 & 41 & 67 & & 90 \\
\hline
\end{tabular}

station. Average concentrations of herbicides ranged from 0.25 to $16.0 \mu \mathrm{g} / \mathrm{L}$ for inflow and 0.11 to $1.67 \mu \mathrm{g} / \mathrm{L}$ for outflow. Total loads for nutrients, suspended sediment, and herbicides generally were higher at the upstream inlet station than at the downstream outlet station. For the July 22 storm, however, the nitrogen load was slightly higher for outflow (13.2 pounds) than for inflow (13.0 pounds). This increase in nitrogen was probably due to the input from the July 20 storm. Combining these two storms, nitrogen was decreased at the outlet by 2 percent. The five-storm load for total nitrogen was reduced by 46 percent. Total phosphorous load was reduced by 41 percent. Total suspendedsediment load was reduced by 67 percent. Metolachlor loads were reduced by 51 percent. The final storm was the only one with measurable concentrations of acifluorfen in runoff. This herbicide was reduced by 90 percent at the outflow. These data demonstrate the ability of the constructed wetland to reduce NPS pollution and to help preserve the aquatic ecosystem.
Constructed wetlands can be built at low cost, require low-maintenance management, and have the potential to become an effective part of agricultural BMP programs. Further study would determine if plant community maturation or design modifications could improve the effectiveness of the constructed wetland to reduce NPS pollution.

\section{REFERENCES CITED}

Eger, P., 1994, Wetland treatment for trace metals removal from mine drainage: The importance of aerobic and anaerobic processes: Water Science Technology, no 29, p. 249-256.

Kadlec, R.H., and Bastiens, W.V., 1992, The use of residence time distributions (RTDs) in wetland systems; The Des Plaines River Wetlands Demonstration Project: Chicago, Ill., Wetlands Research, Inc., 101 p.

Kadlec, R.H., and Kadlec, J.A., 1979, Wetlands and water quality, in Greeson, P.E., Clark, J.R., and Clark. J.E., eds., Wetland functions and values: The state of our understanding: American Water Resources Association, TSP79-2, Minneapolis, Minn., p. 436-456. 
Kennedy, E.G., 1983, Computation of continuous records of streamflow: U.S. Geological Survey Techniques of Water Resources Investigations, Book 3, chapter A13, $53 \mathrm{p}$.

MacDonald, L., 1994, Pollution solution: Build a marsh: American Forests, July, p. 26-29.

Novitzki, R.P., 1979, Hydrologic characteristics of Wisconsin's wetlands and their influence on floods, stream flow and sediment, in Greeson, P.E., Clark, J.R., and Clark, J.E., eds., Wetland functions and values: The state of our understanding: American Water Resources Association, TSP 79-2, Minneapolis, Minn., p. 377-388.

Olson, R.K., 1993, Evaluating the role of created and natural wetlands in controlling nonpoint source pollution,
Created and natural wetlands for controlling nonpoint source pollution: U.S. Environmental Protection

Agency Office of Research and Development and Office of Wetlands, Oceans, and Watersheds: Smoley, Conn., CRC Press, Inc., 69 p.

Suurballe, N., 1991, Effects of a wetland on quality of Natty Pond Brook, Massachusetts, 1985-86: U.S. Geological Survey Water-Resources Investigations Report 91-4144, 52 p.

U.S. Environmental Protection Agency, 1989, Focus on nonpoint source pollution: The Information Broker, U.S. Environmental Protection Agency, Washington, D.C. Office of Water Regulations and Standards, Nonpoint Sources Control Branch, $168 \mathrm{p}$. 


\section{Influence of Riparian Vegetation on the Biological Structure and Processing Function of a Channelized Stream in West Tennessee}

By TOM D. BYL, YUN JIAO, and SUSAN S. HUTSON

U.S. GEOLOGICAL SURVEY

Prepared in cooperation with the U.S. Department of Agriculture, Natural Resources Conservation Service, Shelby County Soil and Water Conservation District, and the University of Memphis Geography Department 
20 


\title{
Influence of Riparian Vegetation on the Biological Structure and Processing Function of a Channelized Stream in West Tennessee
}

\author{
By Tom D. Byl, Yun Jiao*, and Susan S. Hutson
}

\section{Abstract}

The influence of riparian vegetation on the biological structure and processing function of a first-order stream was investigated. This study was conducted by the U.S. Geological Survey, in cooperation with the U.S. Department of Agriculture, Natural Resources Conservation Service; Shelby County Soil and Water Conservation District; and the University of Memphis Geography Department to compare the biologic structure and processing of a herbaceous and a woody reach of stream in the Beaver Creek watershed, West Tennessee. The study stream is located in an agricultural basin planted in row crops and had been channelized for drainage. Herbaceous plants lined the upper reach of the stream, and mature woody vegetation lined the lower reach. Biological and chemical monitoring was done during the 1995 growing season (May-September); the rate of leaf decomposition was measured using leaf packs. Also, qualitative visual observations were made concerning habitat stability. The biological structure and processing function of the herbaceous and woody reaches were compared. The herbaceous reach had a greater diversity and abundance of organisms during spring and early summer than the mature woody reaches. However, the abundance dropped approximately 85 percent during late summer. The woody reach was more stable with regard to $\mathrm{pH}(6.7, \pm 0.3$ compared to $6.6 \pm$ 1.0), dissolved oxygen (5.3 milligrams per liter \pm

\footnotetext{
* Graduate Student, Univ. Memphis, Dept. of Geography, Mem-
} phis, TN 38152
3.2 compared to 6.5 milligrams per liter \pm 7.3 ), and specific conductance (472 microsiemens per centimeter, \pm 438 compared to 302 microsiemens per liter \pm 712 ). The biological community structure was also more constant in the woody reach. The leaves in the leaf packs decomposed approximately 45 percent faster in the herbaceous reach than in the woody reach. The enhanced decomposition could be an effect of the elevated temperatures in the herbaceous reach. The processing function of both reaches was within the ranges reported in the literature.

\section{INTRODUCTION}

Regulatory biomonitoring used to assess stream water quality focuses primarily on structural attributes of the stream biota (Plafkin and others, 1989; Klemm and others, 1990). Examples of structural attributes are abundance and diversity of organisms that live in the stream (Cairns and others, 1992). Studies have shown that the structure of the biological community in the stream reflects the quality of the aquatic environment (Rosenberg and Resh, 1992). The amount of interpretation that can be made from a structural analysis, however, is limited (Byl and Smith, 1994).

More recent monitoring initiatives have called for assessing functional attributes of the stream as well (Cairns and others, 1992; Cairns and McCormick, 1992). One functional attribute of a healthy stream is the ability to process organic material temporally and spatially (for example, leaf decomposition and nutrient cycling). This processing function must occur in a successional manner over the length of a watershed to maintain the health of the aquatic ecosystem (Petersen and Petersen, 1991). For example, plant leaf material needs to be broken down into smaller fragments as it 
moves progressively from low-order to high-order streams. This allows the successive biological communities to take advantage of the food source (Cummins, 1973). Modifying the stream may interrupt the processing continuum and, ultimately, the biological continuum. Thus, stream function needs to be understood and incorporated when attempting to enhance water quality.

Assessment of processing functions, in addition to structural evaluations, is advantageous because (1) it is closely associated with structure; (2) functional attributes provide insight into the results of structure analysis; and (3) a stream may have good structural attributes, but may lack adequate functional attributes that could generate problems downstream. The disadvantage of assessing the function of a stream is the lack of standardized and quantifiable endpoints.

This study was conducted by the U.S. Geological Survey, in cooperation with the U.S. Department of Agriculture-Natural Resources Conservation Service, Shelby County Soil and Water Conservation District, and the University of Memphis Geography Department. The purpose of this study was to evaluate the biological structure and processing function of a small channelized, agricultural stream and to determine if riparian vegetation had any influence on those parameters.

\section{SELECTING THE SAMPLE SITES}

The stream used in this study is a channelized first-order stream in the Beaver Creek watershed in West Tennessee (fig. 1). The stream is approximately 2.5 miles long. The herbaceous and woody reaches used in this study were each approximately 0.6 mile long. During baseflow, the stream is a series of pools and small riffles ranging in depth from 3.28 feet to 0.2 inch, respectively. During high stormflow, the stream becomes a fast flowing channel with depths up to 10 feet. The stream drains an agricultural basin (approximately 500 acres) used to raise row crops. The most common crops were cotton, soybeans, winter wheat, and corn. Some acreage also was used for forestry and grass filter strips. Five pool sites were selected to be sampled and monitored in each of the herbaceous and the woody vegetated reaches. An 11 th site was selected in the transition zone between the herbaceous and woody reaches. Pools were chosen for the study because the riffles were vulnerable to drought and physical alterations during stormflow (Byl and Roman, 1994). The streambanks of the her- baceous and woody reaches were visually examined for active erosion during the study because erosion indicates streambank and habitat instability.

\section{MEASURING THE BIOLOGICAL STRUCTURE AND PROCESSING FUNCTION}

Leaf packs and benthic grab samples were collected three times over the study period to characterize the biological structure of the stream. Benthic macroinvertebrates (organisms retained by a 600 -micrometer mesh sieve) were collected, identified to family, and counted as a measure of biological structure. Rate of leaf decomposition in the leaf pack was used as a simple measure of processing function. This technique has been used in previous studies (Elder and Cairns, 1982; Byl and Roman, 1994). Water chemistry was also monitored to gain more insight into the processing attributes of the two stream reaches.

An initial reconnaissance was done during site selection to assure that organisms inhabited each site. Leaf packs consisted of 20.0 grams of oven dried, whole red oak leaves placed in nylon mesh bags (mesh size $=0.25$ inch). Three bags were placed at each site for a total of 15 bags per vegetative reach. The packs were secured at the sites with wuoden stakes. Five leaf packs from each reach were retrieved 36, 66, and 116 days after they were placed in the stream. Benthic grab samples also were collected at this time following U.S. Environmental Protection Agency procedures (Klemm and others, 1990).

The leaf material was placed in a dish tub and rinsed with water to remove sediment and macroinvertebrates. The macroinvertebrates were collected and preserved with 70 percent isopropyl alcohol for identification and counting. The rinsed leaves were dried in a drying oven and weighed to determine loss of dry weight from the initial weight.

The $\mathrm{pH}$, dissolved oxygen, temperature, turbidity, and specific conductance were measured with a Hydrolab DataSonde-3. Alkalinity was measured using the acid titration method. Each of these constituents was measured at the 11 sites weekly for 11 consecutive weeks. Additionally, daily measurements were made after a rain event to determine how the two systems responded after being flushed. A statistical comparison of the herbaceous and woody riparian reaches was done using the Mann-Whitney rank test. 


\section{TENNESSEE}

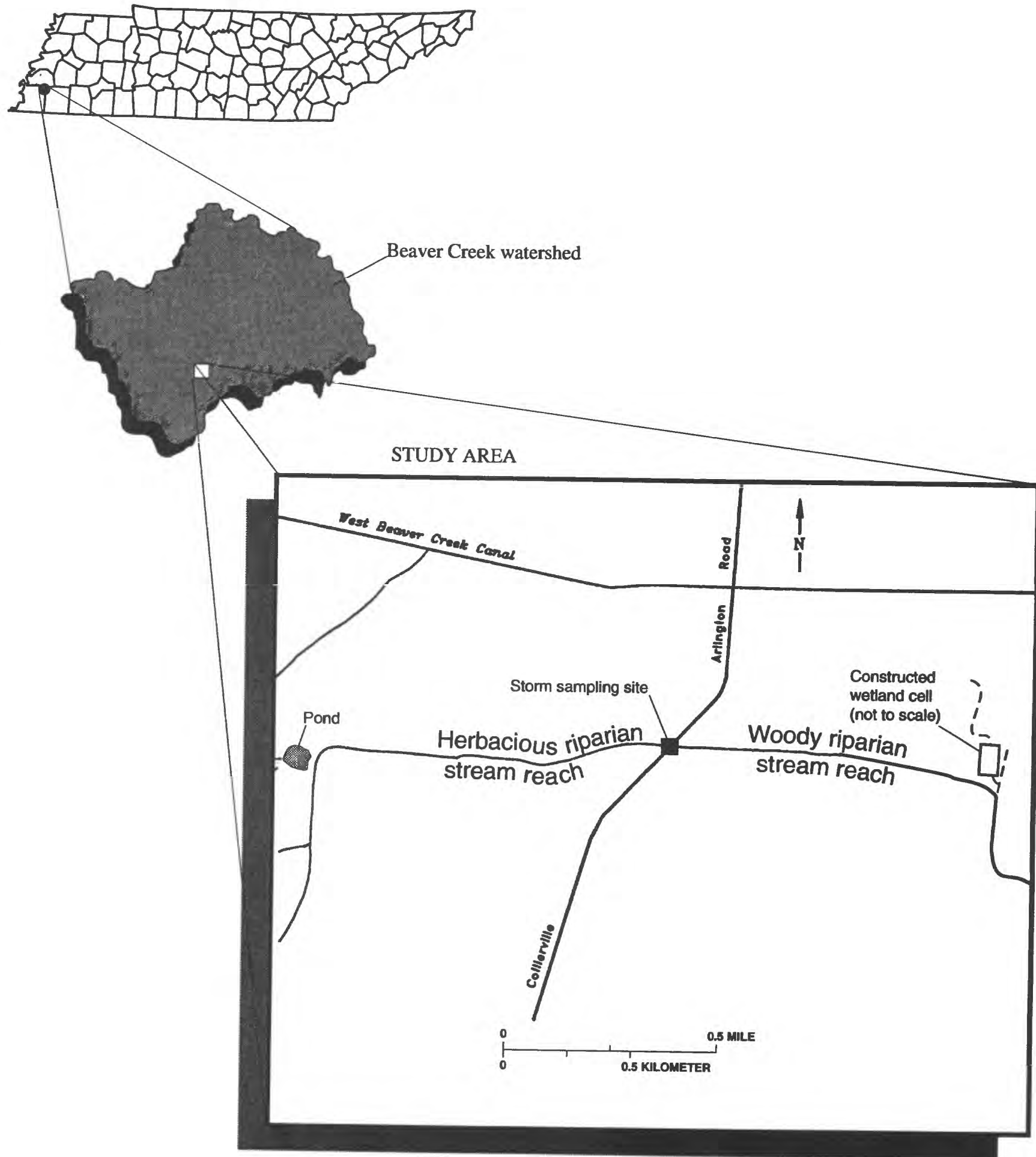

Figure 1. Location of the study area in the Beaver Creek watershed, West Tennessee. 


\section{THE INFLUENCE OF RIPARIAN VEGETATION ON STREAMBANKS}

The streambanks in the herbaceous reach are generally more shallow and broader than those in the woody reach. Where the banks were steep along the herbaceous reach, active erosion and mass wasting was evident. The woody reach had isolated areas where some bank undercutting below the tree roots had occurred. The banks in the woody reach appeared generally more stable than those in the herbaceous reach. However, more down cutting was observed in the woody reach than the herbaceous reach. These observations tend to support the research findings of Shields, Bowie, and Cooper (1995) and Shields, Knight, and Cooper (1995a,b) that trees help to stabilize streambanks. However, trees do not necessarily stabilize the stream bottom.

\section{THE INFLUENCE OF RIPARIAN VEGETATION ON BIOLOGICAL STRUCTURE AND PROCESSING FUNCTION}

Biological samples were collected using sediment grab samples and leaf packs (table 1). The total number of macroinvertebrates was greater in the her- baceous reach than in the woody reach during June and July; however, the population declined 85 percent in the herbaceous reach when sampled in September. The macroinvertebrate abundance and diversity were more constant in the wooded reach. This consistency was probably due to the more stable chemical, hydrologic, and physical environment associated with the woody riparian vegetation.

A reduction in leaf weight was noted in the herbaceous and the woody reaches from May to September. A 60 -percent reduction in weight of the leaf material was recorded from the herbaceous reach, and a 35-percent reduction in leaf weight was recorded in the woody reach (table 1 ). Thus, the rate of leaf decomposition was approximately 45 percent greater in the herbaceous reach compared to the woody reach. This enhanced rate could be due to higher temperatures stimulating faster rates of catabolism as well as a greater number of macroinvertebrates in the herbaceous reach. Both reaches, however, had equal or higher rates of leaf decomposition as compared to a previous study in the same stream (Byl and Roman, 1994) and similar studies in the southeastern United States (Elder and Cairns, 1982; Byl and Roman, 1994; Kittle and others, 1995). Thus the rate of decomposition, which is a measure of stream function, was equal

Table 1. Biomonitoring results in the herbaceous and woody reaches

[Leaf pack counts and weight are reported per average leafpack; <, less than; ${ }^{n} n=1$ for the September herbaceous leaf pack sampling, $\mathrm{n}=3$ at other sites and times]

\begin{tabular}{|c|c|c|c|c|c|}
\hline & $\begin{array}{c}\text { Number of } \\
\text { families }\end{array}$ & $\begin{array}{c}\text { Organisms } \\
\text { per benthic } \\
\text { grab }\end{array}$ & $\begin{array}{l}\text { Organisms } \\
\text { per leaf pack }\end{array}$ & $\begin{array}{l}\text { Leaf pack dry } \\
\text { weight loss } \\
\text { (grams) }\end{array}$ & $\begin{array}{c}\text { Density, number of } \\
\text { organisms per gram of } \\
\text { dry leaf }\end{array}$ \\
\hline \multicolumn{6}{|l|}{ June } \\
\hline Herbaceous & 10 & 482 & 687 & 6.9 & 17 \\
\hline Woody & 9 & 310 & 147 & 4.5 & 3 \\
\hline \multicolumn{6}{|l|}{ July } \\
\hline Herbaceous & 11 & 108 & 1,038 & 8.4 & 15 \\
\hline Woody & 7 & 197 & 354 & 7.1 & 4 \\
\hline \multicolumn{6}{|l|}{ September } \\
\hline Herbaceous & 11 & 3 & $21 *$ & 11.7 & $<1$ \\
\hline Woody & 4 & 67 & 279 & 6.9 & 4 \\
\hline
\end{tabular}


to or greater than rates in comparable streams in the southeastern United States.

Temperature, dissolved oxygen, $\mathrm{pH}$, alkalinity, specific conductance, and turbidity were measured weekly (table 2). The herbaceous reach had greater variability and range in each of these chemical measurements than the woody reach, except for alkalinity (15-268 milliequivelents per liter) and turbidity [203401 nephelometric units (NTU)]. Despite its wider range of turbidity (113-389 NTU), the woody reach's median turbidity value (251 NTU) was less than the herbaceous reach's (291 NTU). Thus, the wooded reach had less turbid waters on average than the herbaceous reach. The weekly water temperature in the herbaceous reach was significantly higher than the temperature in the woody reach. This elevated temperature was probably due to the lack of shade in the herbaceous reach. The median water temperature for the herbaceous reach was $25^{\circ} \mathrm{C}$, and for the wooded reach, $22^{\circ} \mathrm{C}$. This temperature increase is enough to enhance the metabolic rate of bacteria, algae, and other organisms (Stevens and others, 1975). This enhanced metabolic rate would explain why the values were higher for $\mathrm{pH}$ and dissolved oxygen, which are affected by respiration and photosynthesis.

\section{SUMMARY AND DISCUSSION}

Regulatory biomonitoring used to assess stream water quality focuses primarily on structural attributes of the stream biota; more recent monitoring initiatives have called for assessing functional attributes of the stream as well. A study was done to compare the biological structure and processing function of a herbaceous and a woody reach of a first-order stream in the Beaver Creek watershed in West Tennessee. The stream drains a 500 -acre agricultural basin planted in row crops. Eleven sites were evaluated for streambank stability, biological community, rate of leaf decomposition, and water chemistry.

Streambank stability is important to aquatic organisms for habitat stability. Visual observations were made of streambank stability during weekly sampling visits. The herbaceous reach had more streambank erosion than the wooded reach. However, downcutting of the streambed was a problem in the woody reach. Thus, the trees appear to be protecting the streambank, but not the stream bottom. Quantitative assessment could help to verify these qualitative observations.

Biological structure was evaluated in the herbaceous and woody reaches by sampling leaf packs and benthic grab samples from the stream. Leaf packs20.0 grams of oven dried, whole red oak leaves in nylon mesh bags - and benthic grab samples were collected at 36,66 , and 116 days after the leaf packs were placed in the stream to evaluate the abundance of organisms over time. The woody reach had less abundance of macroinvertebrates than the herbaceous reach, but a more stable population over the duration of the study. The biological stability in the woody reach was possibly due to chemical and physical stability - an important feature for sustaining a healthy biological community - provided by the woody riparian vegetation.

Table 2. Range of values and medians for physical and chemical properties

$[\mu \mathrm{S} / \mathrm{cm}$, microsiemens percentimeter; $\mathrm{mg} / \mathrm{L}$, milligrams per liter; meq/L, milliequivelents per liter; NTU, nephelometric units]

\begin{tabular}{|c|c|c|c|c|c|c|}
\hline Stream & Temperature & $\begin{array}{c}\text { Dissolved } \\
\text { oxygen (mg/L) }\end{array}$ & $\begin{array}{c}\text { Alkalinity } \\
\text { (meq/L) }\end{array}$ & $\mathrm{pH}$ & $\begin{array}{c}\text { Specific } \\
\text { conductance } \\
(\mu \mathrm{S} / \mathrm{cm})\end{array}$ & $\begin{array}{c}\text { Turbidity } \\
\text { (NTU) }\end{array}$ \\
\hline & & & Range & & & \\
\hline Herbaceous & $19.7-30.7$ & $3.9-13.8$ & $6.2-7.6$ & $15-268$ & $89-1,013$ & $203-401$ \\
\hline \multirow[t]{2}{*}{ Woody } & $12.7-26.5$ & $2.1-8.5$ & $6.4-7.0$ & $22-282$ & $158-910$ & $113-389$ \\
\hline & & & Median & & & \\
\hline Herbaceous & 24.7 & 6.5 & 6.6 & 100 & 302 & 291 \\
\hline Woody & 21.5 & 5.3 & 6.7 & 124 & 472 & 251 \\
\hline
\end{tabular}


Leaf weight loss was measured as an indicator of a stream processing function. The leaf weight from the herbaceous reach decreased by 60 percent; and in the woody reach, by 35 percent. The leaves decreased in dry weight by an average of 48 percent over a 3-month period. This rate of weight loss from the packaged leaves was comparable to similar studies in the southeastern United States. This weight loss demonstrates that the stream-processing functions operated acceptably when the material was retained by the mesh bags. Natural leaf-retention time in a stream is an important issue when considering stream function (Petersen and Petersen, 1991). This issue was not in the scope of this study, but could be a subject for future studies.

The herbaceous reach has more variability in water chemistry, possibly due to more intense solar radiation. The herbaceous reach had a greater variability and range in each of the measurements than the woody reach, except for alkalinity (15-268 milliequivelents per liter) and turbidity (203-401 NTU). Despite its wider range of turbidity (113-389 NTU), the woody reach's median turbidity value (251 NTU) was less than that of the herbaceous reach (291 NTU).

Well-functioning first-order streams help to maintain more vigorous aquatic ecosystems downstream. Evaluating the processing function of a stream, in addition to the biological structure, provides a better understanding of the stream's health. This study demonstrates that riparian vegetation had an influence on the stability of the streambank. Likewise, riparian vegetation influenced the biological community structure and the processing functions of this stream. In general, the woody reach was more stable with regard to habitat stability, biologic community structure, and water chemistry.

\section{REFERENCES CITED}

Byl, T.D., and Roman, A.J., 1994, Evaluation of biomonitoring techniques used in assessing agricultural nonpoint source pollution, in Pederson, G.L., ed., Symposium on Water Quality, Chicago, 1994, Proceedings: American Water Resource Association, Herndon, VA, p 21-30.

Byl, T.D., and Smith, G.F., 1994, Biomonitoring our streams - what's it all about?: U.S. Geological Survey Open-File Report 94-378, p. 2.

Cairns, J., Jr., and McCormick, P.V., 1992, Developing an ecosystem-based capability for ecological risk assessments: The Environmental Professional, 14, p. 186-196.
Cairns, J., Jr., Niederlehner, B.R. and Smith, E.P., 1992, The emergence of functional attributes as endpoints in ecotoxicology, in Burton, G.A., Jr., ed., Sediment Toxicity Assessment, Chelsea, Mich., Lewis Publishers, Inc.

Cummins, K.W., 1973, Trophic relations of aquatic insects, Annual Review of Entomology, v. 18, p. 183-206.

Elder, J.F., and Cairns, D.J., 1982, Production and decomposition of forest litter fall on the Apalachicola River flood plain, Florida: U.S. Geological Survey WaterSupply Paper 2196-B, p. B1-42.

Kittle, D.L., McGraw, J.B., and Garbutt, K., 1995, Plant litter decomposition in wetlands receiving acid mine drainage: Journal of Environmental Quality, v. 24, p. 301-306.

Klemm, D.J., Lewis, P.A., Fulk, F., and Lazorchak, J.M., 1990, Macroinvertebrate field and laboratory methods for evaluating the biological integrity of surface waters: U.S. Environmental Protection Agency EPA/ 600/4-90/030, Cincinnati, Ohio, 205 p.

Petersen, L.B.M., and Petersen, R.C., Jr., 1991, Short-term retention properties of channelized and natural streams: Verh. Internationale Vereinigugn fuer Theoratische and angewandte Liminologie, v. 24 , no. 3 , p. 867-873.

Plafkin, J.L., Barbour, M.T., Porter, K.D., Gross, S.K., Hughes, R.M., 1989, Rapid Bioassessment protocols for use in streams and rivers: Benthic macroinvertebrates and fish: U.S. Environmental Protection Agency, EPA/444/4-89/001, Cincinnati, Ohio, 165 p.

Rosenberg, D.M., and Resh, V.H., 1992, Introduction to freshwater biomonitoring and benthic macroinvertebrates, in Rosenberg, D.M., and Resh, V.H., eds., Freshwater Biomonitoring and Benthic Macroinvertebrates: New York, Chapman \& Hall, p. 1-33.

Shields, F.D., Jr., Bowie, A.J., and Cooper, C.M., 1995, Control of streambank erosion due to bed degradation with vegetation and structure: Water Resources Bulletin, v. 31 , p. $475-489$.

Shields, F.D., Jr., Knight, S.S., and Cooper, C.M., 1995a, Streambank protection and habitat restoration, in Proceedings of the 1st International Conference Water Resources Engineering Division/American Society of Civil Engineers, San Antonio, Tex., p. 721-725.

1995b, Rehabilitation of watersheds with incising channels: Water Resources Bulletin, v. 31, p. 971-982.

Stevens, H.H., Jr., Ficke, J.F., and Smoot, G.F., 1975, Water temperature-influenced factors, field measurements, and data presentation: Techniques of Water-Resources Investigations of the United States Geological Survey, Book 1, Chapter D1, 65 p. 
Transport of Aldicarb and Aldicarb Metabolites in Runoff from Agricultural Fields in the Beaver Creek Watershed, West Tennessee

By SHANNON D. WILLIAMS

U.S. GEOLOGICAL SURVEY

Prepared in cooperation with the Tennessee Department of Agriculture 
28 


\section{Transport of Aldicarb and Aldicarb Metabolites in Runoff from Agricultural Fields in the Beaver Creek Watershed, West Tennessee}

\section{By Shannon D. Williams}

\section{Abstract}

Aldicarb and its metabolites were detected in runoff during several rainfall events monitored from 1991 to 1995 . The maximum concentrations detected were 410,68 , and 14 micrograms per liter for aldicarb, aldicarb sulfoxide, and aldicarb sulfone, respectively. These concentrations were detected during rain events occurring shortly after the application of aldicarb to fields. Aldicarb concentrations detected in runoff samples were below analytical detection limits within a few weeks of aldicarb application. Aldicarb sulfoxide and aldicarb sulfone were more persistent, with concentrations of about 1 microgram per liter detected as late as 76 days after aldicarb application. The data indicated that a potential exists for significant transport of aldicarb and its metabolites if severe rain events occur shortly after the application of aldicarb.

\section{INTRODUCTION}

Pesticides transported in runoff from cropland may have detrimental effects on water quality and aquatic biological communities in receiving streams. In 1989, the U.S. Geological Survey (USGS) entered into a cooperative agreement with the Tennessee Department of Agriculture to assess the effect of agricultural activities on water quality in the Beaver Creek watershed in West Tennessee (fig. 1). One objective of the project was to quantify the transport of pesticides from agricultural fields.

About 70 percent of the 95,000 acres in the Beaver Creek watershed is under row-crop cultivation with cotton, soybeans, corn, and winter wheat being the major crops. Aldicarb is a carbamate pesticide, which is widely used as an insecticide and nematicide for cotton crops in the Beaver Creek watershed and other areas of West Tennessee. This report describes the transport of aldicarb and its metabolites, aldicarb sulfoxide and aldicarb sulfone, in storm runoff in a first order stream draining 422 acres in the Beaver Creek watershed.

The stream is located in a bottomland area with land slopes ranging from 2 to 12 percent. Soils in the drainage area are classified as silt loams, with the principal soil series being the Falaya series. Falaya silt loam is a somewhat poorly drained, very silty, nearly level soil (U.S. Department of Agriculture, Soil Conservation Service, 1989). Approximately 90 percent of the 422 acres in the drainage area is under cultivation of cotton, corn, soybeans, and winter wheat. The number of acres of cotton grown was 59 in 1991, 93 in 1992, 102 in 1993, and 113 in 1995. The application rate for aldicarb was 0.67 pound per acre of the active ingredient.

\section{ALDICARB PROPERTIES}

Aldicarb is relatively toxic by oral, dermal, and inhalation routes of exposure. LC50 (median lethal concentration) values for bluegill sunfish and rainbow trout are reported as 50 and 560 micrograms per liter $(\mu \mathrm{g} / \mathrm{L})$, respectively (U.S. Environmental Protection Agency, 1988). Although aldicarb is considered toxic, organisms tend to exhibit a more rapid and spontaneous recovery from poisoning by carbamates than from poisoning by other types of pesticides, such as organophosphorus compounds (Fukuto, 1987).

Aldicarb is applied to cropland in a granular form and is typically incorporated into the soil during planting. Degradation of aldicarb begins immediately after application. Aldicarb rapidly degrades to aldicarb sulfoxide through oxidation, followed by slower 


\section{TENNESSEE}
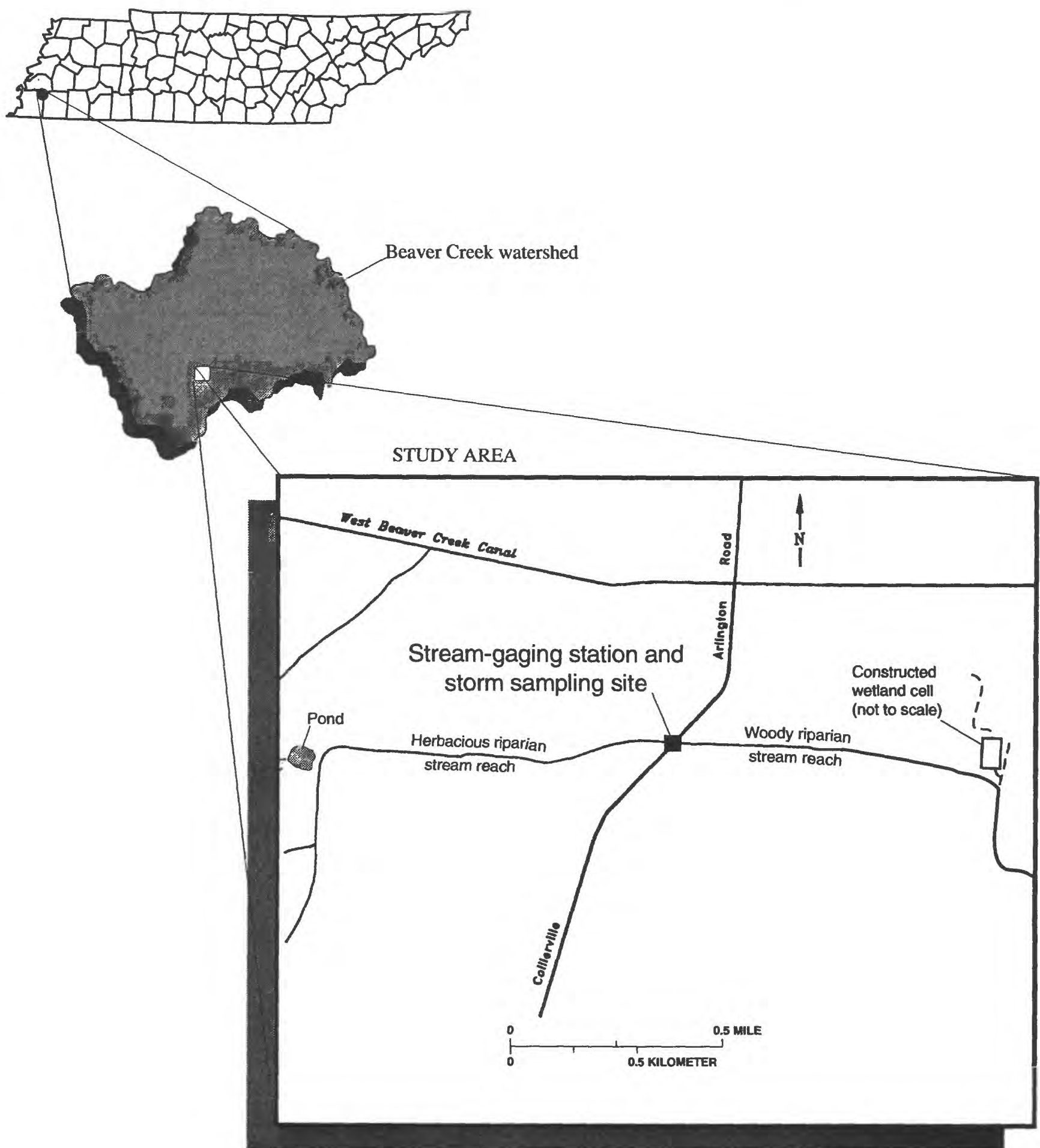

Figure 1. Location of the study area at the Beaver Creek watershed, West Tennessee. 
oxidation to aldicarb sulfone (Hanson and Spiegel, 1983; Lightfoot and others, 1987). Aldicarb and its metabolites also hydrolyze to form noncarbamate oximes and nitriles, which have relatively low toxicities and which continue to degrade to even less toxic compounds (Fukuto, 1987; Lightfoot and others, 1987). Half-lives for aldicarb, aldicarb sulfoxide, and aldicarb sulfone in surface soils have been reported to range from 0.5 to 3 months, depending upon environmental conditions, such as $\mathrm{pH}$ and temperature (Lightfoot and others, 1987; Olsen and others, 1994).

Aldicarb is generally considered to be highly water soluble. Normally characterized as having high leaching and low surface runoff potential, aldicarb is not expected to move horizontally from a bare, sloping field (U.S. Environmental Protection Agency, 1988). Because of these properties, most studies that have examined the fate and transport of aldicarb focused on the vertical transport of aldicarb through the soil profile and were mainly concerned with the leaching of aldicarb and its metabolites into ground water.

Previous studies conducted by the USGS in West Tennessee indicate that little aldicarb and its metabolites are leaching into ground water in the Beaver Creek area (Olsen and others, 1994). A study examining the transport and degradation of aldicarb in the soil profile in the Beaver Creek watershed indicated minimal vertical transport of aldicarb and its metabolites was occurring (Olsen and others, 1994). These findings are supported by the results of a ground-water quality study for the shallow aquifers in the watershed and surrounding areas. Aldicarb was not detected in water samples collected from almost 400 domestic wells in Shelby, Tipton, Fayette, and Haywood Counties (Fielder and others, 1994). The apparent lack of vertical movement of aldicarb in the soil profile indicates that in West Tennessee more potential exits for transport of aldicarb in surface runoff than normally would be expected.

\section{DATA COLLECTION AND ANALYSIS}

Water samples for the determination of aldicarb and its metabolites were collected at a USGS streamgaging station using automatic samplers (fig. 1). Water samples were collected during selected rainfall/runoff events from 1991 through 1995, normally at 5- to 15-minute intervals. Upon collection, samples were chilled in ice and sent to laboratories for analyses.
Water samples collected from 1991 to 1993 were sent to The Institute of Wildlife and Environmental Toxicology (TIWET) at Clemson University for analysis of aldicarb, aldicarb sulfoxide, and aldicarb sulfone. Extraction of samples was performed using TIWET standard operational procedure 401-53-01. Extracted samples were analyzed using reverse-phase high pressure liquid chromatography (HPLC). Analytical detection limits for aldicarb and its metabolites were $0.33 \mu \mathrm{g} / \mathrm{L}$ in 1991 and $0.67 \mu \mathrm{g} / \mathrm{L}$ thereafter. Water samples collected during 1995 were sent to the USGS Water-Quality Laboratory in Ocala, Florida, for analysis of aldicarb. These samples were analyzed using enzyme linked immunosorbent assay (ELISA) methods, which have an estimated detection limit of $0.25 \mu \mathrm{g} / \mathrm{L}$ for aldicarb (Olsen and others, 1994).

Hydrographs and chemographs for each rainfall event were prepared to examine discharge and concentration patterns. Discharge was calculated with stagedischarge rating curves developed by using methods described by Kennedy (1983). Loads (L) for individual runoff events were calculated using the sum of individual interval loads:

where

$$
L=\sum_{i=1}^{n} c_{i} q_{i} t_{i} K
$$

$c_{i}$ is the ith interval of sampled concentration, $q_{i}$ is the instantaneous discharge at the time the sample was collected,

$t_{i}$ is the time interval associated with the sample, $K$ is a unit conversion factor, and $n$ is the number of samples.

This method assumes that the sampled concentration and the corresponding discharge value are representative of the time interval $t_{i}$, that is equal to half the time from the preceding sample to the current sample plus half the time from the current sample to the following sample.

\section{TRANSPORT OF ALDICARB}

During a storm occuring 7 days after aldicarb application in 1991, concentrations of aldicarb and its metabolites increased rapidly as stormflow began, peaked shortly before the peak discharge, and then declined rapidly (fig. 2). Hydrographs and chemographs for other storm events typically exhibited the same patterns. These results indicate that aldicarb and 


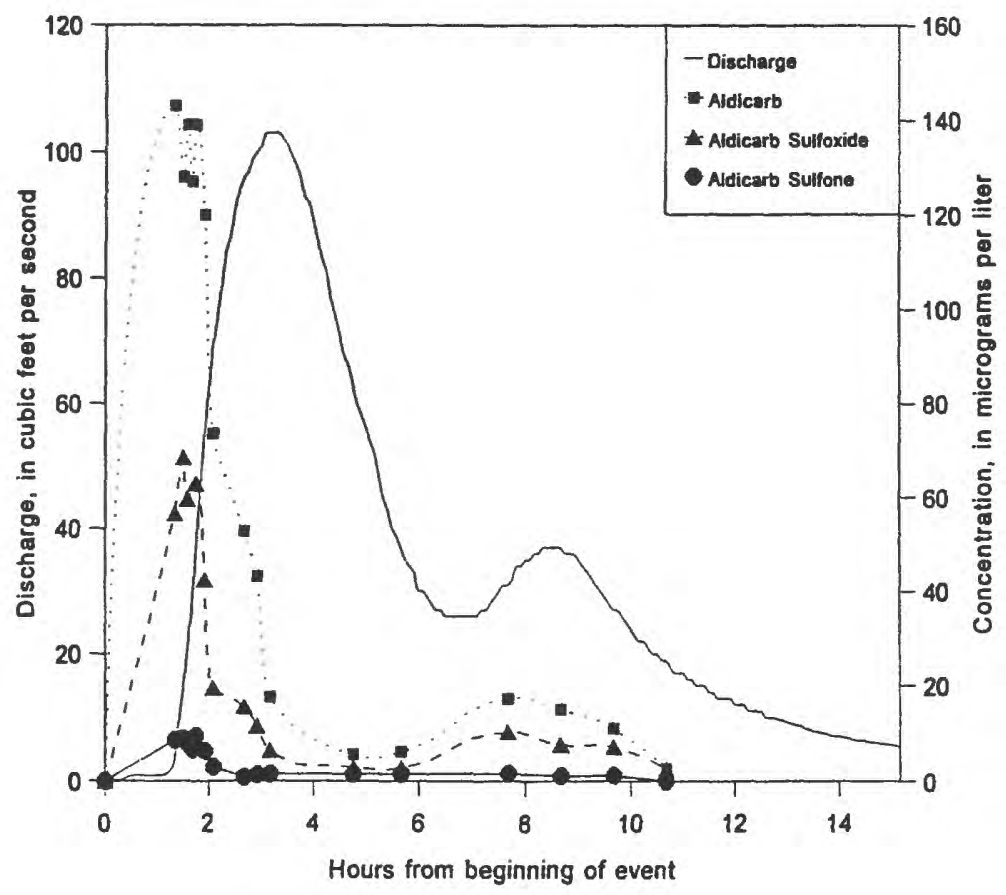

Figure 2. Hydrograph and chemograph for a rainfall/runoff event on May 25, 1991.

its metabolites are transported in solution from surface and near surface soils.

\section{Concentrations}

Aldicarb and its metabolites were detected in runoff during several storms (table 1). The maximum concentrations of aldicarb, aldicarb sulfoxide, and aldicarb sulfone detected were 410,68 , and $14 \mu \mathrm{g} / \mathrm{L}$, respectively. The highest concentrations of aldicarb and aldicarb sulfoxide were detected during rainfall/ runoff events occurring a few hours to a few day after aldicarb application. Maximum aldicarb sulfone concentrations appear to occur in rainfall/runoff events occurring several days to a few weeks after aldicarb application, which is consistent with the aldicarb degradation process to aldicarb sulfoxide which then degrades to aldicarb sulfone.

Many of the aldicarb, aldicarb sulfoxide, and aldicarb sulfone concentrations detected are at levels that could possibly be detrimental to aquatic organisms based on reported toxicity data (Landau and Tucker, 1984; Foran and others, 1985; U.S. Environmental Protection Agency, 1988; Fisher, 1991). Most of the reported toxicity data, however, are based on exposure times of 48 to 96 hours. Concentrations of aldicarb and its metabolites at the study site tended to peak within a few hours after the beginning of a rainfall event, and they tended to return to relatively low levels sooner than 48 hours. Therefore, the toxic effects of aldicarb and its metabolites on organisms at the study site may not be as great as those reported in the literature.

Aldicarb concentrations in the runoff samples collected were below detection limits within a few weeks after aldicarb application. However, the aldicarb metabolites were detectable at low concentrations in runoff for a longer period of time. Concentrations of about $1.0 \mu \mathrm{g} / \mathrm{L}$ for both metabolites were detected in samples collected during a rainfall/runoff event occurring 76 days after application in 1993.

The results for samples collected during 1995 were determined using enzyme-linked immunosorbent assay kits for aldicarb that cannot distinguish between aldicarb and its metabolites. The detected concentrations likely consisted mostly of aldicarb sulfoxide and aldicarb sulfone instead of aldicarb itself. The concentrations detected were consistent with the combined concentrations of aldicarb and its metabolites detected during previous years at similar times after aldicarb application. 


\section{Loads}

For the storm events examined, the largest transport of aldicarb and its metabolites in storm runoff occurred on May 25, 1991 (table 1). The highest maximum load values of aldicarb, aldicarb sulfoxide, and aldicarb sulfone were all recorded after the storm on May 5, 1991. The values detected were 1,100, 420, and 41 grams, respectively. Approximately 9 percent of the aldicarb applied in 1991 was transported from the drainage area during this event. Almost 2 inches of rain was deposited on the drainage area during this storm, which occurred 7 days after aldicarb was applied to fields. The total percentage of aldicarb transported from fields in runoff each year could not be estimated since data were collected only during a few rainfall/runoff events.

Maximum concentrations detected in storm runoff on May 18, 1993 were much higher than those detected on May 25, 1991; however, smaller loads of aldicarb and its metabolites occurred during the
May 18, 1993 storm. The concentrations were higher because this storm occurred within a few hours of aldicarb application. The storm loads were lower even though concentrations were higher because the rainfall/runoff event was relatively small. Only 0.2 inch of rainfall occurred during this storm, and the peak discharge was 93 percent lower than the peak discharge on May 25, 1991.

\section{SUMMARY}

In 1989, the U.S. Geological Survey entered into a cooperative agreement with the Tennessee Department of Agriculture to assess the impact of agricultural activities on water quality in the Beaver Creek watershed in West Tennessee. Aldicarb is a carbamate pesticide, which is widely used as an insecticide and nematicide for cotton crops in the 95,000-acre Beaver Creek watershed, 70 percent of

Table 1. Summary of aldicarb, aldicarb sulfoxide, aldicarb sulfone concentrations and loads measured during selected rainfall/runoff events from 1991 to 1995

[ft ${ }^{3} / \mathrm{s}$, cubic feet per second, $\mu \mathrm{g} / \mathrm{L}$, micrograms per liter, --, data not available; <, less than; *, results determined using enzyme-linked immunosorbent assay methods that detect aldicarb and its sulfoxide and sulfone metabolites]

\begin{tabular}{|c|c|c|c|c|c|c|c|c|c|}
\hline \multirow[b]{2}{*}{$\begin{array}{c}\text { Storm } \\
\text { date }\end{array}$} & \multirow{2}{*}{$\begin{array}{c}\text { Days } \\
\text { after } \\
\text { aldicarb } \\
\text { appli- } \\
\text { cation }\end{array}$} & \multirow[b]{2}{*}{$\begin{array}{c}\text { Total } \\
\text { rainfall } \\
\text { (inches) }\end{array}$} & \multirow[b]{2}{*}{$\begin{array}{c}\text { Peak } \\
\text { discharge } \\
\left(\mathrm{ft}^{3} / \mathrm{s}\right)\end{array}$} & \multicolumn{3}{|c|}{ Maximum concentrations } & \multicolumn{3}{|c|}{ Loads } \\
\hline & & & & $\begin{array}{c}\text { Aldicarb } \\
(\mu \mathrm{g} / \mathrm{L})\end{array}$ & $\begin{array}{c}\text { Aldicarb } \\
\text { sulfoxide } \\
(\mu \mathrm{g} / \mathrm{L})\end{array}$ & $\begin{array}{c}\text { Aldicarb } \\
\text { sulfone } \\
(\mu g / L)\end{array}$ & $\begin{array}{c}\text { Aldicarb } \\
\text { (grams) }\end{array}$ & $\begin{array}{c}\text { Aldicarb } \\
\text { sulfoxide } \\
\text { (grams) }\end{array}$ & $\begin{array}{l}\text { Aldicarb } \\
\text { sulfone } \\
\text { (grams) }\end{array}$ \\
\hline $05 / 25 / 91$ & 7 & 1.98 & 100 & 140 & 68 & 9.5 & 1,100 & 420 & 41 \\
\hline $06 / 11 / 91$ & 24 & 0.8 & 27 & 20 & 14 & 14 & 15 & 9.7 & 12 \\
\hline $06 / 12 / 91$ & 25 & 0.2 & 18 & 2.4 & 9.5 & 11 & 0.2 & 1.1 & 3.8 \\
\hline 07/03/91 & 46 & -- & 33 & $<0.33$ & 0.41 & 3.6 & 0.0 & 0.03 & 5.2 \\
\hline $07 / 24 / 91$ & 67 & -- & 19 & $<0.33$ & $<0.33$ & $<0.33$ & 0.0 & 0.0 & 0.0 \\
\hline 08/09/91 & 83 & - & 59 & $<0.33$ & $<0.33$ & $<0.33$ & 0.0 & 0.0 & 0.0 \\
\hline $10 / 30 / 91$ & 165 & - & 3 & $<0.33$ & $<0.33$ & $<0.33$ & 0.0 & 0.0 & 0.0 \\
\hline $11 / 01 / 91$ & 167 & - & 19 & $<0.33$ & $<0.33$ & $<0.33$ & 0.0 & 0.0 & 0.0 \\
\hline $06 / 26 / 92$ & 47 & 2.0 & 47 & $<0.67$ & 3.4 & 4.2 & 0.0 & 11 & 14 \\
\hline $05 / 18 / 93$ & 0 & 0.2 & 8 & 410 & 42 & 2.1 & 520 & 81 & 0.31 \\
\hline $08 / 02 / 93$ & 76 & 1.9 & 90 & $<0.67$ & 1.0 & 1.4 & 0.0 & 13 & 21 \\
\hline $06 / 06 / 95$ & 14 & 0.9 & 21 & $* 28$ & -- & -- & -- & -- & -- \\
\hline $06 / 11 / 95$ & 19 & - & -. & $* 34$ & - & -- & - & -- & -- \\
\hline $06 / 21 / 95$ & 29 & 0.1 & 3 & $* 36$ & - & - & -- & -- & - \\
\hline $06 / 25 / 95$ & 33 & 0.7 & 14 & $* 19$ & -- & -- & -- & -- & -- \\
\hline
\end{tabular}


which is under row-crop cultivation with cotton, soybeans, corn, and winter wheat.

Soils in the drainage area are classified as silt loams, with the principal soil series being the Falaya series-a somewhat poorly drained, very silty, nearly level soil. Previous studies indicate that these soils and physical characteristics of the drainage area may limit the vertical movement of aldicarb and its metabolites through the soil profile, keeping them in surface and near-surface soils. Therefore, aldicarb and its metabolites may be more susceptible to be transported in surface runoff than normally would be expected.

Water samples for the determination of aldicarb and its metabolites were collected during selected rainfall/runoff events from 1991 to 1995 , normally at 5- to 15-minute intervals. Analytical detection limits for aldicarb and its metabolites were $0.33 \mu \mathrm{g} / \mathrm{L}$ in 1991 and $0.67 \mu \mathrm{g} / \mathrm{L}$ thereafter. Hydrographs and chemographs for each rainfall event were prepared to examine discharge and concentration patterns. Concentrations of aldicarb and its metabolites increased rapidly as stormflow began, peaked shortly before the peak discharge, and then declined rapidly. These results also indicate that aldicarb and its metabolites are transported in solution from surface and nearsurface soils.

The highest concentrations of aldicarb and its metabolites in rainfall/runoff events occurred shortly after aldicarb application, before adequate time had elapsed for these substances to be degraded. The highest concentrations detected were 410,68 , and $14 \mu \mathrm{g} / \mathrm{L}$ for aldicarb, aldicarb sulfoxide, and aldicarb sulfone, respectively. Aldicarb appeared to degrade relatively fast, with little aldicarb $(<0.67 \mu \mathrm{g} / \mathrm{L})$ detected in storm runoff occurring a few weeks after aldicarb application. However, the aldicarb metabolites $(1.0 \mu \mathrm{g} / \mathrm{L})$ were detected in storm runoff occurring as long as 76 days after application.

Several of the aldicarb, aldicarb sulfoxide, and aldicarb sulfone concentrations exceeded values reported in toxicity data for various aquatic organisms. However, the exposure times to high concentrations of aldicarb and its metabolites at the study site are significantly shorter than the exposure times used to develop the toxicity data, making the toxic effects of aldicarb and its metabolites at the study site difficult to determine.

After the storm on May 25, 1991, the highest maximum load values of aldicarb, aldicarb sulfoxide, and aldicarb sulfone were all recorded at 1,100,420, and 41 grams, respectively. Approximately 9 percent of the aldicarb applied in 1991 was transported from the drainage area during the May 25, 1991 storm. Data from the May 25, 1991 and the May 18, 1993 storms indicate that the potential exists for significant losses of aldicarb and its metabolites if severe rain events occur soon after pesticide application.

\section{SELECTED REFERENCES}

Fielder, A.M., Roman-Mas, Angel, and Bennett, M.W., 1994, Reconnaissance of ground-water quality at selected wells in the Beaver Creek watershed, Shelby, Fayette, Tipton, and Haywood Counties, West Tennessee, July and August 1992: U.S. Geological Survey Open-File Report 93-366, 28 p.

Fisher, S.W., 1991, Changes in the toxicity of three pesticides as a function of environmental $\mathrm{pH}$ and temperature: Bulletin of Environmental Contamination and Toxicology, v. 46, no. 2, p. 197-202.

Foran, J.A., Germuska, P.J., and Delfino, J.J., 1985, Acute toxicity of aldicarb, aldicarb sulfoxide, and aldicarb sulfone to daphnia laevis: Bulletin of Environmental Contamination and Toxicology v. 35, no. 4, p. 546-550.

Fukuto, T.R., 1987, Organophosphorus and carbamate esters: The anticholinesterase insecticides: Fate of Pesticides in the Environment, Proceedings of a Technical Seminar, p. 5-18. Oakland, Ca., Division of Agriculture and Natural Resources, University of Ca., $158 \mathrm{p}$.

Hansen, J.L., and Spiegel, M.H., 1983, Hydrolysis studies of aldicarb, aldicarb sulfoxide and aldicarb sulfone: Environmental Toxicology and Chemistry, v. 2, p. 147-153.

Kennedy, E.G., 1983, Computation of continuous records of streamflow: U.S. Geological Survey Techniques of Water Resources Investigations, Book 3, chapter A13, $53 \mathrm{p}$.

Landau, M., and Tucker, J.W., Jr., 1984, Acute toxicity of EDB and aldicarb to young of two estuarine fish species: Bulletin of Environmental Contamination and Toxicology, v. 33, no. 2, p. 127-132.

Lightfoot, E.N., Thorne, P.S., Jones, R.L., Hansen, J.L., and Romine, R.R., 1987, Laboratory studies on mechanisms for the degradation of aldicarb, aldicarb sulfoxide and aldicarb sulfone: Environmental Toxicology and Chemistry, v. 6, p. 377-394.

Olsen, L.D., Roman-Mas, A., Weisskopf, C.P., and Klaine, S.J., 1994, Transport and degradation of aldicarb in the soil profile: A comparison of conventional tillage and non-tillage: Proceedings of the American Water Resources Association National Symposium on Water Quality, p. 31-42. Herndon, Va.: American Water Resources Association, $321 \mathrm{p}$.

U.S. Department of Agriculture, Soil Conservation Service, 1989, Soil survey of Shelby County, Tennessee: Washington, D.C., U.S. Government Printing Office, 56 p. and 90 maps.

U.S. Environmental Protection Agency, 1988, Pesticide fact sheet: Aldicarb: Washington, D.C., Office of Pesticide Programs, $7 \mathrm{p}$. 